
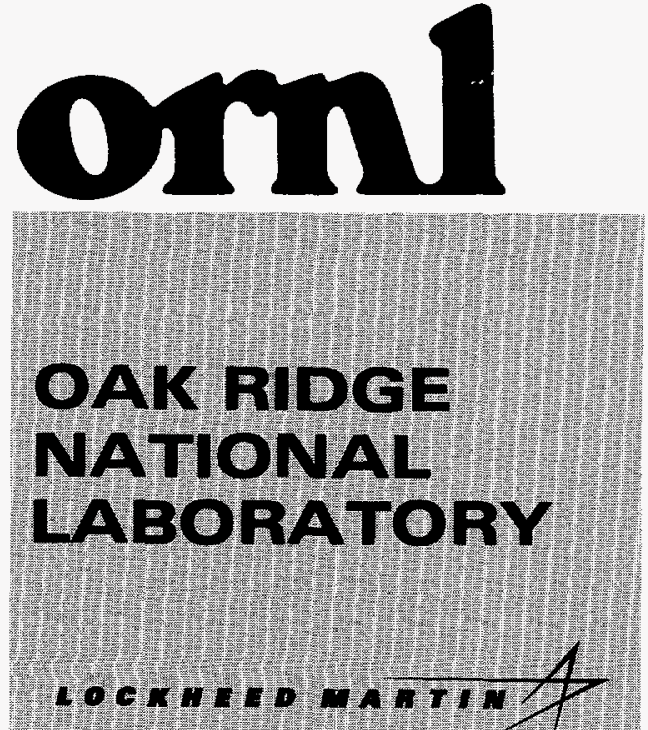

NAMAEB WO OPERTTED EY

LOOKHED IMHM ENERGY RESEARCH CORPOAMTON FORTHE UTIESTATES

DEPARTUEM OF EREROT
ORNL/TM-13184

RECEIVED

MAY 161996

OSTI

\section{Assessment of Potential ORNL Contributions to Supply of Molybdenum-99}

C. L. Ottinger

E. D. Collins 
This report has been reproduced directly from the best available copy.

Available to DOE and DOE contractors from the Office of Scientific and Technical Information, P.O. Box 62, Oak Ridge, TN 37831; prices avaliable from (615) 576-8401, FTS 626-8401.

Available to the public from the National Technical Information Service, U.S. Department of Commerce, 5285 Port Royal Rd., Springfield, VA 22161.

This report was prepared as an account of work sponsored by an agency of the United States Government. Neither the United States Government nor any agency thereof, nor any of their employees, makes any warranty, express or implied, or assumes any legal liability or responsibility for the accuracy, completeness, or usefulness of any information, apparatus, product, or process disclosed, or represents that its use would not infringe privately owned rights. Reference herein to any specific commercial product, process, or service by trade name, trademark, manufacturer, or otherwise, does not necessarlly consttute or imply its endorsement, recommendation, or favoring by the United States Government or any agency thereof. The views and opinions of authors expressed herein do not necessarily state or reflect those of the United States Government or any agency thereof. 


\author{
Chemical Technology Division \\ ASSESSMENT OF POTENTIAL ORNL CONTRIBUTIONS TO \\ SUPPLY OF MOLYBDENUM-99 \\ C. L. Ottinger* \\ E. D. Collins
}

*Consultant.

April 1996

Prepared by the

OAK RIDGE NATIONAL LABORATORY

Oak Ridge, Tennessee 37831-6285

managed by

LOCKHEED MARTIN ENERGY RESEARCH CORP

for the

U.S. DEPARTMENT OF ENERGY

under contract DE-AC05-96OR22464 
$\cdot$
$\bullet$ 


\section{CONTENTS}

$\underline{\text { Page }}$

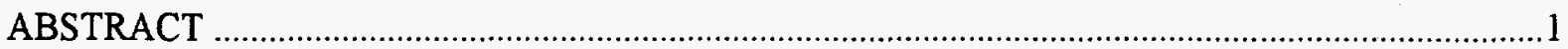

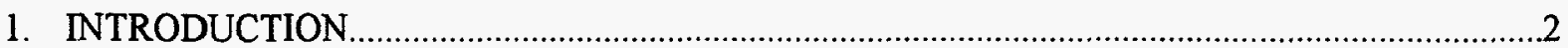

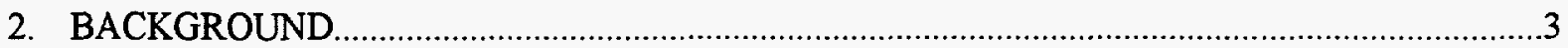

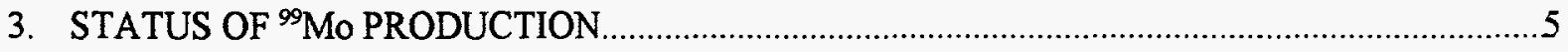

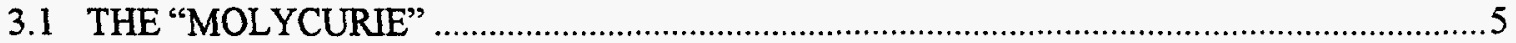

3.2 CURRENT METHODS FOR PRODUCTION AND DISTRIBUTION OF ${ }^{99} \mathrm{Mo} \ldots \ldots \ldots \ldots \ldots \ldots . . . . . . . . . . . .5$

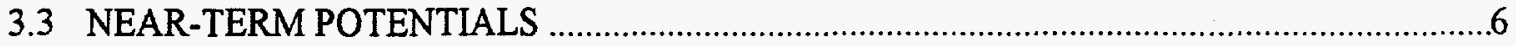

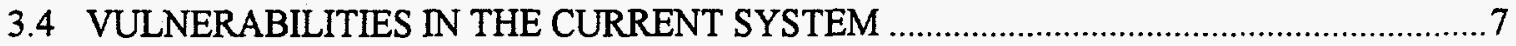

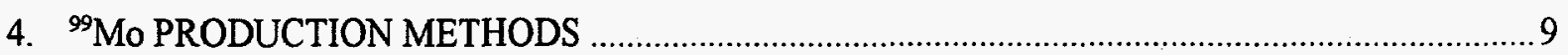

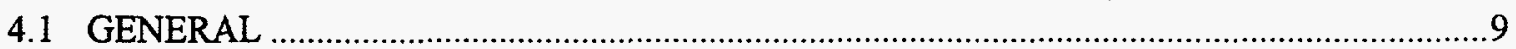

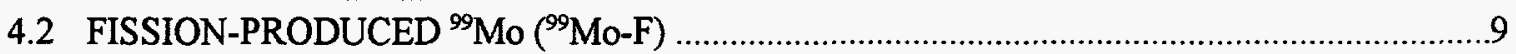

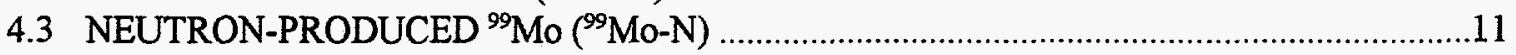

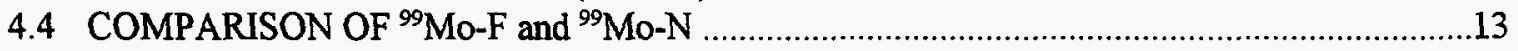

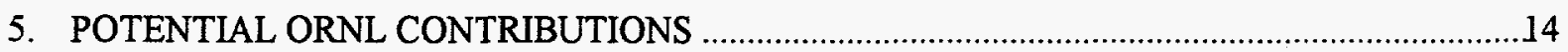

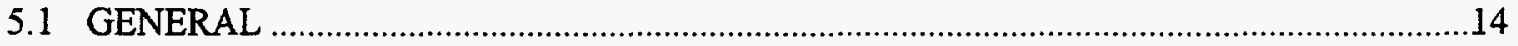

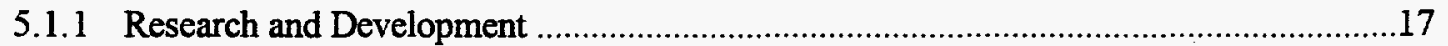

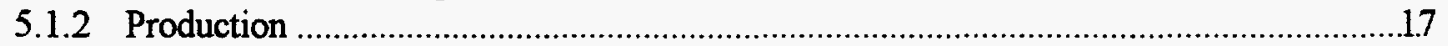

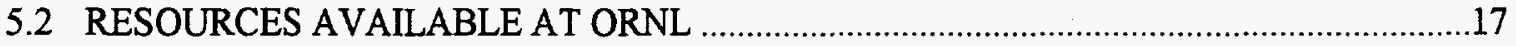

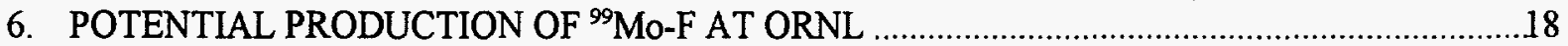

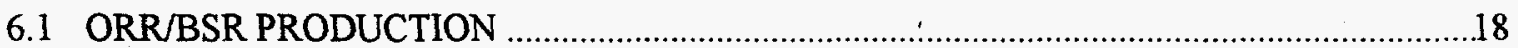

6.2 HFIR PRODUCTION

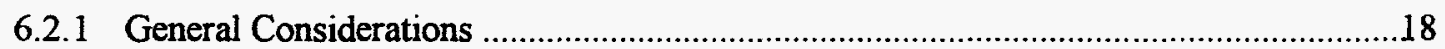

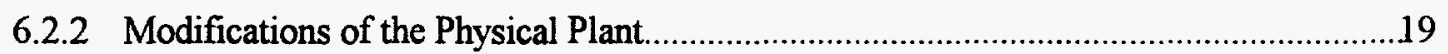

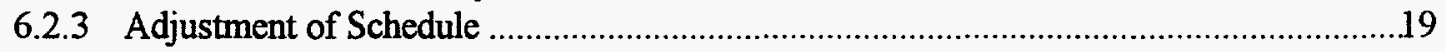

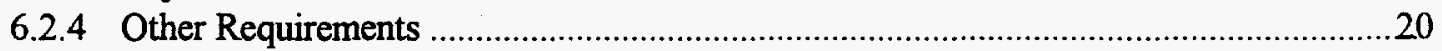

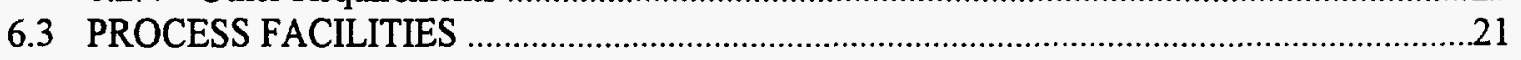

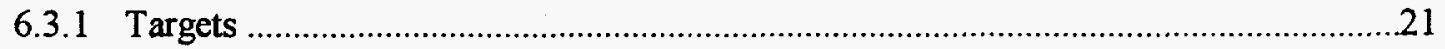

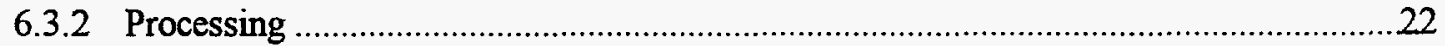

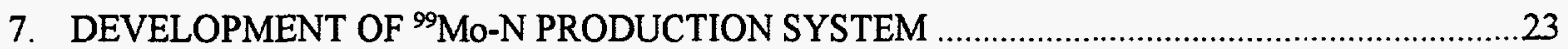

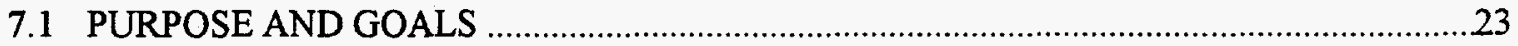

7.2 DEVELOPMENT PLAN FOR ${ }^{99} \mathrm{MO}-\mathrm{N}$

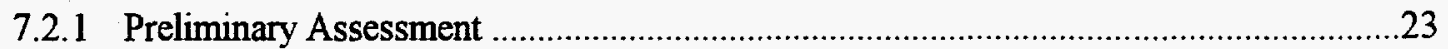

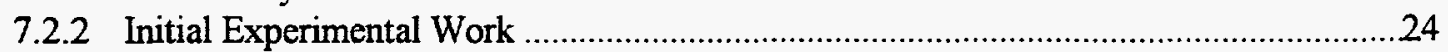

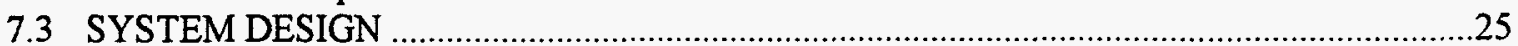




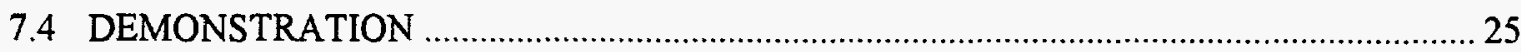

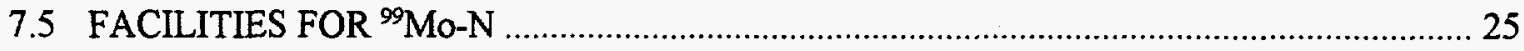

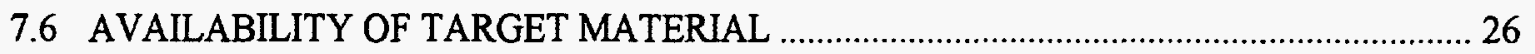

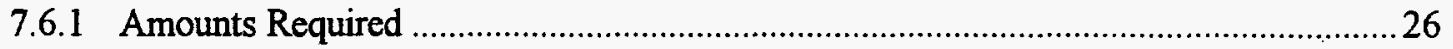

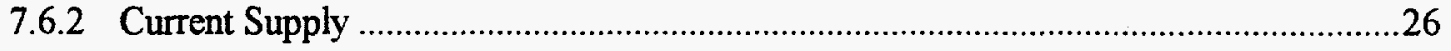

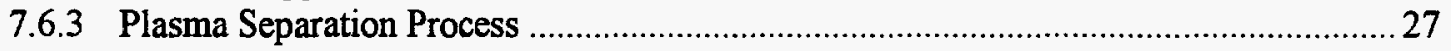

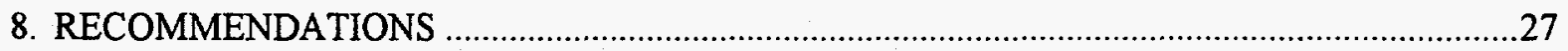

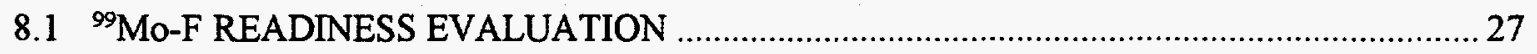

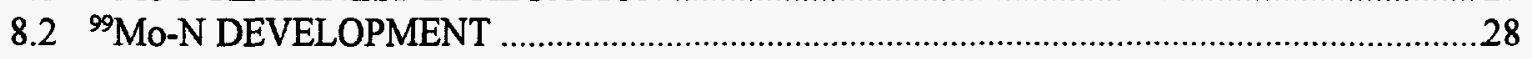

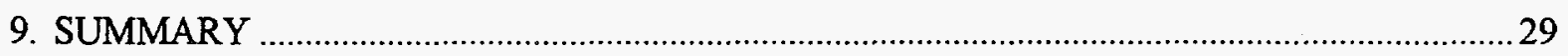

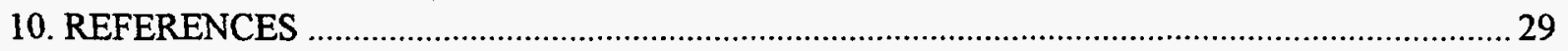

Appendix A. MEMORANDUM FROM W. E. HILL TO R. L. STOVER, DATED AUGUST 17,1995 


\title{
ASSESSMENT OF POTENTIAL ORNL CONTRIBUTIONS TO SUPPLY OF MOLYBDENUM-99
}

\begin{abstract}
The most widely used, and probably the most important, single radioisotope in commerce is ${ }^{99} \mathrm{Mo}$. Although the present supply is adequate, there are many vulnerabilities in the supply picture. Resources available at ORNL could be applied to help ensure the continued availability of this critically needed radioisotope. This assessment considers the ways in which ORNL might participate in DOE efforts to develop and maintain a domestic source of ${ }^{99} \mathrm{Mo}$ for medical needs. The primary recommendation presented here is that ORNL obtain DOE support for development of an improved method for providing ${ }^{99} \mathrm{Mo}$ to the user community. Specifically, development and demonstration of a system based on irradiation of enriched stable ${ }^{98} \mathrm{Mo}$, as opposed to fission of ${ }^{235} \mathrm{U}$, is recommended. Such a system would (1) alleviate the need for using highly enriched uranium as target material (nonproliferation and criticality safety concerns); (2) alleviate the need to produce a large volume of unwanted fission product wastes (safety and cost concerns); (3) promote the need for enriched ${ }^{98} \mathrm{Mo}$, which can be produced in the ORNL calutrons or plasma separation equipment; and (4) promote the need for a high-flux reactor, such as the High Flux Isotope Reactor (HFIR).
\end{abstract}




\section{INTRODUCTION}

Applications of radioisotopes in diagnostic medicine have increased continuously in the half century since these materials began to be routinely available. Today, approximately one-third of the 40 to 50 million diagnostic procedures performed annually in the United States are done with radioisotopes. The most widely used radioisotope in nuclear medicine is technetium- $99 m\left({ }^{99 m} \mathrm{Tc}\right)$, the 6-h daughter of 66-h molybdenum-99 ( $\left.{ }^{99} \mathrm{Mo}\right)$. Based on various recent studies, ${ }^{99 m} \mathrm{Tc}$ is used in approximately $70 \%$ of all radioisotope diagnostic procedures, or on the order of ten million procedures per year. ${ }^{1-4}$

Several factors combine to make ${ }^{99 m} \mathrm{Tc}$ a highly useful radioisotope: (1) It can be chemically incorporated into a wide range of diagnostic pharmaceutical agents, permitting selectivity for various procedures. (2) The radiation emitted, while easily detected, is relatively low energy, thus reducing the total radiation dose to the patient. (3) Its short half-life also contributes to minimization of dose. (4) Usable amounts of the parent ${ }^{99} \mathrm{Mo}$ and associated ${ }^{99 m} \mathrm{Tc}$ can be transported to the medical facility in small packages. (5) Separation of the ${ }^{99 m} \mathrm{Tc}$ and incorporation into diagnostic agents is simple and direct. (6) The short half-lives of both ${ }^{99} \mathrm{Mo}$ and ${ }^{99 m} \mathrm{Tc}$ result in essentially no radiological waste problems at the use site. (7) For the present, at least, ${ }^{99} \mathrm{Mo}$ is available on demand at reasonable cost.

In addition to the societal benefits of improved health care, the use of ${ }^{99 \mathrm{~m}} \mathrm{Tc}$ supports an economic system on the order of $\$ 3$ billion to $\$ 4$ billion per year in the United States at the delivery (i.e., the patient) level. As is the case with any radioisotope, the demand can be influenced in either direction by changing technology. Negative influences include improvement in efficiency of use and replacement by different agents, but there is no significant indication that either of these is likely. Positive influences include new applications, expansion of use in present locations, and development of new markets. Of these, the last is expected to have the largest near-term effect, especially in Pacific Rim countries. ${ }^{2}$

Currently, physicians who practice nuclear medicine in the United States are totally dependent on foreign suppliers for ${ }^{99} \mathrm{Mo} /{ }^{99 m} \mathrm{Tc}$. For practical purposes, they are dependent on a single foreign supplier, Nordion International of Canada. Some efforts have been made toward expanding the production in Europe and in South Africa; however, there are no realistic possibilities of a major increase in availability from other current foreign producers or from new producers, foreign or domestic, except for the Department of Energy (DOE).*

*As used in this report, the terms Department of Energy, Department, and DOE may refer to the current agency or to either of its predecessor agencies, the Atomic Energy Commission and the Energy Research and Development Administration, depending on the time context. 
Recognizing the vulnerability of the current single-source supply of this critical radioisotope, DOE is presently developing capability for production of ${ }^{99} \mathrm{Mo}$ at facilities at Sandia National Laboratory (SNL). Although still in the early stages, this initiative is expected to result in a system under which DOE will supply a significant fraction of the U.S. demand and have the capacity to supply all of the demand at need. Full- capacity operation is currently projected to be in place by late 1998 .

Given that the DOE initiative is successful, the risk of a serious shortfall in ${ }^{99} \mathrm{Mo}$ availability will be substantially reduced, but it will not be eliminated. Therefore, it is advisable to consider other alternatives for ${ }^{99} \mathrm{Mo}$ production within the DOE complex. The extent to which any such consideration may be pursued will depend ultimately on a decision by the Department. At the least, periodic updates should be made relative to the potential for ${ }^{99} \mathrm{Mo}$ production at various DOE sites.

The purpose of the assessment presented here is to evaluate potential contributions that could be made by Oak Ridge National Laboratory (ORNL) in the event of a major, long-term shortage of ${ }^{99} \mathrm{Mo}$ from other sources. It is assumed that DOE will successfully establish production on schedule and, thereafter, will be providing a significant share of the U.S. need on a routine basis. Further, it is assumed that any growth in demand will be at a rate commensurate with the combined abilities of the two major suppliers, DOE and Nordion, to increase production, but that a point will be reached at which neither could ensure full supply alone. The assessment is based on studies of fission-produced ${ }^{99} \mathrm{Mo}$ made by ORNL in 1991 updated to present conditions plus evaluation of another possibility, the improved production of ${ }^{99} \mathrm{Mo}$ by irradiation of ${ }^{98} \mathrm{Mo}$.

\section{BACKGROUND}

Clinical use of ${ }^{99} \mathrm{Mo} / 99 m \mathrm{Tc}$ developed from work done under DOE support during the early years. Characterization, pharmaceutical agent synthesis, production studies, and preclinical work were carried out primarily at Brookhaven National Laboratory (BNL), while initial production of commercial quantities was the responsibility of ORNL. Throughout this period, clinical applications of ${ }^{99 m} \mathrm{Tc}$ depended on ${ }^{99}$ Mo produced by neutron irradiation of targets of molybdenum, either natural $\left(24 \%{ }^{98} \mathrm{Mo}\right)$ or enriched $\left(95+\%{ }^{98} \mathrm{Mo}\right)$. The product provided to the end user was either a solution of ${ }^{99 \mathrm{~m}} \mathrm{Tc}$ separated from ${ }^{99} \mathrm{Mo}$ or a generator on which ${ }^{99} \mathrm{Mo}$ in equilibrium with ${ }^{99 m} \mathrm{Tc}$ was deposited. The ${ }^{99 m} \mathrm{Tc}$ delivery system, while beneficial to the end users, imposed severe logistical problems because of the short halflife of the radioisotope $(6 \mathrm{~h})$, limiting the geographical area that could be served. The low specific 
activity of the ${ }^{99} \mathrm{Mo}$ produced by neutron irradiation in reactors available at the time resulted in bulky generator systems, which required large volumes of reagents and were difficult to handle by end users.

A carrier-free ${ }^{99} \mathrm{Mo}$ produced by fission was recognized to be superior to neutron-produced material in terms of generator size and operational convenience. Initially, some resistance was encountered from the user community because of the change to fission-produced ${ }^{99} \mathrm{Mo}$. The primary concern was the potential for contamination of the product, especially with ${ }^{131} \mathrm{I}$ and alpha-emitting radioisotopes. This concern, which does not apply to neutron-produced ${ }^{99} \mathrm{Mo}$, was alleviated by the demonstration of process and quality control procedures adequate to ensure acceptable products.

In the mid-1960s, following some production developments at BNL, ORNL began supplying fission-produced ${ }^{99}$ Mo to the user community. Atomic Energy of Canada, Limited (AECL), later to become Nordion International, also began providing the material. Two private U.S. organizations, General Electric Vallecitos (GE) and Union Carbide, Sterling Forest (UC), developed production capacity for fission-produced ${ }^{99} \mathrm{Mo}$, resulting in DOE's withdrawal from production. The GE reactor shut down in 1977, leaving only AECL and UC as major producers for the North American demand. In 1989 , the UC operation, which had previously been sold to a foreign concern (Cintichem), also ceased operation.

In 1991, the DOE, through its Isotope Production and Distribution Program (IPDP), initiated a project to establish a domestic source of supply by DOE production. The IPDP obtained the Cintichem production technology under a purchase/royalty agreement. Various DOE sites, including ORNL, submitted proposals based on use of the Cintichem process. The IPDP selected Los Alamos National Laboratory (LANL) as the production site, intending to use the Omega West Reactor (OWR) and the LANL process facilities with appropriate modifications. The work was initiated, but the OWR was shut down in late 1992. Because the costs to restart the OWR were considered prohibitive, this project was abandoned. In 1995, the IPDP decided to pursue ${ }^{99}$ Mo production at SNL using the Annular Core Research Reactor (ACRR).

The ORNL proposal in 1991 considered two options to provide backup irradiation capacity: restart of the Oak Ridge Research Reactor (ORR) only and restart of both the ORR and the Bulk Shielding Reactor (BSR). In each case, the Radioisotope Development Laboratory (RDL), Building 3047, with modifications, was the only processing facility proposed. Because the IPDP had specified use of the Cintichem technology, no other approaches were considered by ORNL at the time. Technically, the ORNL proposal had high merit because of the availability of both a production reactor and a backup reactor, as well as a processing facility-all in close geographical proximity. 


\section{STATUS OF ${ }^{99}$ Mo PRODUCTION}

\subsection{THE "MOLYCURIE"}

Discussions of ${ }^{99} \mathrm{Mo}$ production and distribution can, at times, become confused because of different interpretations of curie quantity. Both the short half-life and the method of marketing contribute to discrepancies. From a business perspective, the significant quantity is the curie that the customer pays for, usually called the "invoice curie." However, there are other stages of the operation at which the curie quantity needs to be defined. The five main stages are as follows:

- The "reactor curie" refers to the curie content of the target at discharge from the reactor.

- The "process curie" (i.e., the reactor curie minus process losses and decay) refers to the curie yield in the separation/purification process.

- The "shipped curie" (i.e., the process curie minus loading losses and decay) is the total quantity shipped to the customer.

- The "receipt curie" (i.e., the shipped curie minus decay during shipment) is the quantity actually received by the customer at time of receipt.

- The "invoice curie" (i.e., the receipt curie adjusted for a contractual decay allowance, typically $6 \mathrm{~d}$ ) is the curie quantity billed to the customer.

The relative values of these quantities will vary with production and shipping schedules; however, for typical systems, the invoice curie will be only 5 to $10 \%$ of the reactor curie.

\subsection{CURRENT METHODS FOR PRODUCTION AND DISTRIBUTION OF ${ }^{99} \mathrm{Mo}$}

The three basic components of the ${ }^{99}$ Mo system are: (1) production of the purified ${ }^{99}$ Mo product, (2) processing and generator preparation, and (3) final use. Production involves target preparation, irradiation, processing of the irradiated target to obtain a ${ }^{99} \mathrm{Mo}$ product, and delivery of the product to the radiopharmaceutical manufacturer. The radiopharmaceutical manufacturer converts the ${ }^{99} \mathrm{Mo}$ into the forms needed by the end users. In most cases, the ${ }^{99} \mathrm{Mo}$ is delivered to the end user in the form of a generator with the ${ }^{99} \mathrm{Mo}$ sorbed onto a solid ion-exchange medium. Radiopharmaceutical manufacturers typically also provide "kits" that contain the appropriate reagents to permit the user to remove the ${ }^{99 m} \mathrm{Tc}$ from the generator and chemically incorporate it into the specific diagnostic agent(s) required for organ 
imaging. Generator sizes, types, and contents vary with the requirements of users and with the resources available at the user sites. Most user sites are hospitals staffed by nuclear medicine professionals and support personnel, but few of them have the facilities or expertise for more than the most basic chemical processing. In some cases, centralized nuclear pharmacies provide ${ }^{99 m} \mathrm{Tc}$ agents to multiple hospitals in the same geographic area.

Many factors combine to make ${ }^{99} \mathrm{Mo}$ production and distribution logistically complex. These include: (1) user's needs, (2) short half-lives of ${ }^{99} \mathrm{Mo}$ and ${ }^{99 m} \mathrm{Tc}$, (3) wide distribution of user sites, (4) operating characteristics of reactors, (5) status of process facilities, (6) waste and environmental issues, and (7) technical and regulatory considerations. Although overall demand is relatively stable, needs can fluctuate on a daily basis, depending on the mix of requirements represented by the thousands of individual users. Because of the nature of ${ }^{99 m} \mathrm{Tc}$ use, "emergency" deliveries are uncommon, and most requirements can be planned a few weeks in advance.

The use of ${ }^{99 m} \mathrm{Tc}$ represents a level of economic activity that is on the order of $\$ 3$ billion to $\$ 4$ billion dollars per year at the delivery (i.e., the patient) level, but the producer's share of this is only a little more than $1 \%$. The total world demand is on the order of 4000 invoice curies per week. Market growth or decline may be influenced in either direction by new technology, but the general trend is one of modest growth ( $\sim 5 \%$ per year). The demand is currently being supplied by one major producer, Nordion International of Canada, plus some smaller producers in Europe and Russia. Nordion has a long and outstanding record as a reliable supplier. In 1991, however, one of the two reactors formerly available to Nordion was shut down, and construction of a planned new reactor was delayed, leaving only one reactor in service for ${ }^{99} \mathrm{Mo}$ production. Collectively, the European producers could possibly, but not assuredly, scale up production to replace the Nordion supply in the event of a shutdown at that facility. Even if the inherent capacity for such scaleup exists, the time required would still result in an unacceptable shortterm situation.

\subsection{NEAR-TERM POTENTIALS}

Nordion has recently described plans for replacing the delayed Maple X reactor with a system of two reactors sharing a common processing facility. ${ }^{5,6}$ Although an on-line date of late 1998 has been mentioned, no actual construction has started, so such a date may be overly optimistic.

DOE is actively pursuing the establishment of ${ }^{99}$ Mo production capacity by modifying the ACRR at SNL to a continuous-operation mode and upgrading existing facilities at SNL for processing. A staged approach is planned, leading to establishment of limited capacity in late 1996 and full capacity for U.S. 
demand by late 1998. Basically, the operation involves conversion of the ACRR to full-time operation at $4 \mathrm{MW}$ and installing process capability. Barring unforeseen events, the project appears to have a good probability of success. The current schedule is reasonable; however, DOE has recently decided to prepare a full Environmental Impact Statement (EIS) for the project. This action, along with the public hearings and responses associated with it, will have a tendency to extend the schedule.

In Europe, production capacity using five reactors is being increased but will probably plateau at approximately $50 \%$ of total demand. Other possible near-term contributors to the overall supply are reactors in the former Soviet Union, Australia, the Far East, South Africa, and South America. For the assessment presented here, it is assumed that (1) DOE will be successful in its present initiative; (2) the combined European capacity will be scaled up to $50 \%$ of the total demand; (3) the collective capacity of all other near-term contributors will be less than $50 \%$ of total demand; and (4) the new Canadian reactor will not be completed before the end of this century.

\subsection{VULNERABILITIES IN THE CURRENT SYSTEM}

Any production system is controlled by various conditions that could limit or terminate the capacity. Changes in the economic situation, applicable government regulations, user or public acceptance, and competition from either other producers or alternative technologies can have detrimental effects on ${ }^{99} \mathrm{Mo}$ or any other commodity. Relative to ${ }^{99} \mathrm{Mo}$ specifically, all current or contemplated production systems depend, to some extent, on government support, and changes in government policies, regardless of whether they are related directly to ${ }^{99} \mathrm{Mo}$, can adversely affect ${ }^{99} \mathrm{Mo}$ production. Even relatively shortterm situations such as labor problems and interruption of transport systems can have very serious consequences for ${ }^{99} \mathrm{Mo}$, which is produced and used on a frequency measured in days and cannot be stockpiled.

All of the aforementioned vulnerabilities are quite real, and they should be evaluated in any overall consideration pertaining to the maintenance of a reliable supply of ${ }^{99} \mathrm{Mo}$. Each will have its own likelihood of occurrence and severity of impact, but these vulnerabilities are not directly addressed here. Rather, this assessment deals with the vulnerability represented by the loss of the physical ability to produce ${ }^{99} \mathrm{Mo}$ at one or more of the major current, or currently planned, production sites. This could result from a prolonged, or permanent, reactor shutdown or from a shutdown of the ${ }^{99} \mathrm{Mo}$ processing system. Any production system is subject to shutdown for a variety of reasons, such as equipment or facility failure, inability to comply with operating requirements, loss of supply of appropriate feed material, termination of other missions, unacceptable increase in operating cost, as well as others. The 
most likely reason for shutdown of a process facility dedicated to ${ }^{99} \mathrm{Mo}$ would probably be release of radioactivity from waste fission products.

One particular vulnerability of a process system is the need to control, and ultimately to dispose of, the large amounts of fission product wastes that are produced in the target in addition to the ${ }^{99} \mathrm{Mo}$. Some of these have very short half-lives, and radioactive decay during processing effectively controls them. Others with relatively long half-lives are present in limited amounts because of the method of target irradiation. The group of most concern consists of those with half-lives from a few days to several months. Chief among these is ${ }^{131} \mathrm{I}$, which has a half-life of $8 \mathrm{~d}$ and is produced in quantities comparable to the ${ }^{99} \mathrm{Mo}$. The potential for release of ${ }^{131} \mathrm{I}$ must be controlled to the very lowest practical minimum. Not only the real hazard, but also the perceived hazard, must be recognized. Depending on its chemical and physical environment, ${ }^{131} \mathrm{I}$ can appear in several forms, including gaseous. Thus, the control of this radioisotope becomes a major consideration in both the design and operation of the facility. The radioactive noble gases, primarily ${ }^{133} \mathrm{Xe}$, must be trapped and held for decay. Other radioisotopes, although not present in comparable amounts, must be disposed of on a continuous basis to prevent buildup of total radioactivity in the system. Unconsumed highly enriched uranium must also be treated and removed from the system, requiring strict accountability and other measures to maintain criticality safety. Unless the ${ }^{99} \mathrm{Mo}$ process system can deal with these residual materials, in the sense of control during processing and removal from the system afterward, it will be forced to shut down.

The precise reason for loss of production capacity is immaterial to this assessment. The basic premise is that the many vulnerabilities in the current system will, at some undefined future time, cause the supply of ${ }^{99} \mathrm{Mo}$ to drop below the demand and the then-current producers will not be able to compensate for the shortage. Without a ${ }^{99}$ Mo production system already in place and ready for immediate startup, such a situation will create a crisis in U.S. health care.

No one in the ${ }^{99}$ Mo user community or other knowledgeable groups disagrees that a serious shortage of ${ }^{99}$ Mo would have an immediate and highly detrimental effect on medical practice. However, opinions as to the probability of occurrence of such a shortage are mixed. The Society of Nuclear Medicine has voiced its concerns directly to the Secretary of Energy, and this, undoubtedly, had some influence on the DOE's decision to pursue ${ }^{99}$ Mo production. Recently, two national scientific organizations have made overall reviews of the current situation relative to isotope supply in the United States. ${ }^{3,4}$ The conclusions reached by these two groups were in essential agreement in all areas of isotope supply except one-the ${ }^{99} \mathrm{Mo}$ situation. The Committee on Biomedical Isotopes of the Institute of Medicine recommended that the DOE not establish ${ }^{99} \mathrm{Mo}$ capability, based on the adequacy of existing sources. In sharp contrast, the 
Senior Scientists and Engineers Program of the American Association for the Advancement of Science stated emphatically that the ${ }^{99}$ Mo problem must be solved and was supportive of DOE efforts in that direction.

\section{4. ${ }^{99}$ Mo PRODUCTION METHODS}

\subsection{GENERAL}

Currently, only two methods of ${ }^{99}$ Mo production will yield the quantities needed: (1) fission of ${ }^{235} \mathrm{U}$, and (2) neutron irradiation of stable ${ }^{98} \mathrm{Mo}$. All of the ${ }^{99} \mathrm{Mo}$ used in the United States is produced by fission, but neutron-produced material is still in fairly wide use in some countries. The basic difference between the products from the two processes is the amount of ${ }^{99} \mathrm{Mo}$ radioactivity per unit weight of molybdenum, referred to as the "specific activity" and usually expressed as curies per gram. The specific activity of fission-produced ${ }^{99} \mathrm{Mo}$ is higher than that of reactor-produced ${ }^{99} \mathrm{Mo}$ by two to four orders of magnitude. It is important to note, however, that the actual radionuclide administered in the clinical procedure, ${ }^{99 m} \mathrm{Tc}$, is the same, regardless of the type of ${ }^{99} \mathrm{Mo}$ used.

In a broad sense, the resources needed to produce ${ }^{99} \mathrm{Mo}$ by either method are the same-a source of targets, a reactor, and a process system, along with appropriate support services. Among the differences between the two types of production processes are: the target materials, the amounts of radioactive waste produced, the complexities of the chemical processes, and the specific types of physical resources needed. Fission production requires targets of highly enriched uranium, while neutron production uses stable molybdenum. The fission process generates large quantities of radioactive waste, but the neutron process generates virtually none. A multistage chemical process is required for the fission-produced material as compared with a very simple and rapid process for neutron-produced material. A relatively small volume of reactor space with moderate neutron flux suffices for fission production, but neutron production needs more space and a higher flux. Both the processing and the waste facilities for fission-produced ${ }^{99} \mathrm{Mo}$ are larger, more complex, and more costly than those needed for neutron-produced ${ }^{99} \mathrm{Mo}$.

\subsection{FISSION-PRODUCED ${ }^{99} \mathrm{Mo}\left({ }^{99} \mathrm{Mo}-\mathrm{F}\right)$}

Currently, the ${ }^{99} \mathrm{Mo}-\mathrm{F}$ on the market is generated from the fission of "highly enriched uranium" (HEU) with a ${ }^{235} \mathrm{U}$ enrichment of $90 \%$ or greater. There is no fundamental reason not to use material with lower enrichments, but the HEU results in physically smaller targets, lower volumes of process 
chemicals, and other advantages. Fabrication of the targets entails all of the radiological handling problems, criticality control, security, and nuclear material accountability common to HEU. The targets must also be amenable to the particular reactor and the position in the reactor in terms of effect on reactivity and control of fission/gamma heating. Thus, target design involves a trade-off between reactor requirements and postirradiation processing convenience. Targets made from alloys of uranium with aluminum, as well as targets containing uranium plated on metal, have been used successfully; other types could also be used.

High reactor power and high flux are not necessities for ${ }^{99} \mathrm{Mo}-\mathrm{F}$ production. Power levels in the 2 to $10-\mathrm{MW}$ range are adequate, and low-flux zones $\left(10^{13}-10^{14}\right.$ neutrons $\left.\mathrm{cm}^{-2} \mathrm{~s}^{-1}\right)$ can be used. More important factors are: (1) availability of target positions that are of appropriate size to produce ${ }^{99} \mathrm{Mo}-\mathrm{F}$ in a period commensurate with production requirements, and (2) positions that can be accessed on demand to meet user requirement schedules.

Specific requirements vary among customers, resulting in a mix of desired delivery times and amounts. For a viable production system, delivery on a semiweekly basis would probably be a minimum rate. Although exact schedules would differ with facility and process conditions, certain factors are common to all production modes: (1) a cooling period between discharge and processing, (2) processing, (3) assay, (4) loading for shipment, and (5) delivery to the customer. The cooling period is necessary to reduce the target radioactivity and heat from decay of isotopes with very short half-lives. Process time is determined primarily by target design and chemistry. Assay is necessary to ensure that the product is acceptable. Loading includes measuring and dispensing of customer-specific orders and preparation of packages for shipment. Shipping times depend on common carrier schedules, but overnight delivery in the United States is routine. A representative process schedule, with the amount of ${ }^{99} \mathrm{Mo}$ at each step, is given in Table 1, which assumes semiweekly processing at a rate equivalent to $50 \%$ of current estimated U.S. demand. In this example, the invoice curie is $8 \%$ of the reactor curie.

Processing of ${ }^{99} \mathrm{Mo}-\mathrm{F}$ requires heavily shielded, contained facilities to conduct the postirradiation recovery process, which involves chemical separation of ${ }^{99} \mathrm{Mo}$ from a wide spectrum of fission products, uranium, and inert target components. Radioactive gases must be controlled and contained, and unconsumed uranium must be accounted for. The process generates large amounts of radioactive wastes that are difficult and expensive to dispose of. A target contains much more unwanted radioactivity than ${ }^{99} \mathrm{Mo}$; and even though most of the radionuclides are short-lived, they must eventually be disposed of as radioactive waste. The exact composition of the waste stream will vary with the specific irradiation 
Table 1. Representative process schedule for ${ }^{99} \mathrm{Mo}-\mathrm{F}$

\begin{tabular}{|c|c|c|c|c|c|}
\hline Operation & $\begin{array}{c}\text { Operation } \\
\text { time (h) }\end{array}$ & $\frac{\text { Elaps }}{(\mathrm{h})}$ & $\frac{\text { time }}{\text { (d) }}$ & $\begin{array}{l}{ }^{99} \mathrm{Mo} \text { at end of } \\
\text { operation (Ci) }\end{array}$ & $\begin{array}{c}\% \text { of reactor } \\
\text { curie }\end{array}$ \\
\hline Discharge from reactor & 0 & 0 & 0 & 12,500 & 100 \\
\hline Cooling; transfer to process & 24 & 24 & 1 & 9,740 & 78 \\
\hline $\begin{array}{l}\text { Processing, assay (assumes } 10 \% \text { process } \\
\text { loss) }\end{array}$ & 24 & 48 & 2 & 6,830 & 55 \\
\hline $\begin{array}{l}\text { Preparation for shipment (assumes } \\
5 \% \text { loading loss) }\end{array}$ & 12 & 60 & 2.5 & 5,730 & 46 \\
\hline Shipment to customer & 24 & 84 & 3.5 & 4,460 & 36 \\
\hline Decay allowance & 144 & 228 & 9.5 & 1,000 & 8 \\
\hline
\end{tabular}

conditions, but all wastes resulting from ${ }^{99} \mathrm{Mo}-\mathrm{F}$ production will be of the same general composition. Figure 1 shows the approximate rate of radioactive waste accumulation for a semiweekly process producing $50 \%$ of the U.S. demand. The trends observed here are based on irradiation of $93 \%{ }^{235} \mathrm{U}$ at a nominal flux of $2 \times 10^{14}$ neutrons $\mathrm{cm}^{-2} \mathrm{~s}^{-1}$ for $7 \mathrm{~d}$. Individual trends are shown for ${ }^{133} \mathrm{Xe}$, which must necessarily be handled as a separate stream, and for ${ }^{131} \mathrm{I}$, which is usually also treated separately. The other radioisotopes are grouped as "mixed fission products," which includes those with moderate halflives from 3 to $65 \mathrm{~d}$. A 3-week period is shown, yielding a total of 6000 invoice curies of ${ }^{99} \mathrm{Mo}$. In practice, obviously, the waste would be removed from the system at a rate commensurate with the approved facility limits. Regardless of the accumulation limits, the waste streams would have to be isolated so as not to interfere with processing. Some of these "waste" radioisotopes, especially ${ }^{131}$ I and ${ }^{133} \mathrm{Xe}$, have definite markets, but the total demands are far below the amounts generated.

The final ${ }^{99}$ Mo product delivered to the customer must be extremely pure because the ${ }^{99 m} \mathrm{Tc}$ recovered from it is used in humans. Therefore, several separated process areas must be used to control contamination with the fission products or with other alpha-emitting radioisotopes in the system. Quality control and quality assurance practices must be rigid.

\subsection{NEUTRON-PRODUCED ${ }^{99} \mathrm{Mo}\left({ }^{99} \mathrm{Mo}-\mathrm{N}\right)$}

The target for ${ }^{99} \mathrm{Mo}-\mathrm{N}$ production is stable molybdenum. Natural molybdenum can be used, but the highest practical enrichment in ${ }^{98} \mathrm{Mo}$ is preferred to enhance production rate. Enrichments in excess of $95 \%$ are routinely available, providing an increase in production rates of a factor of 4 as compared with 


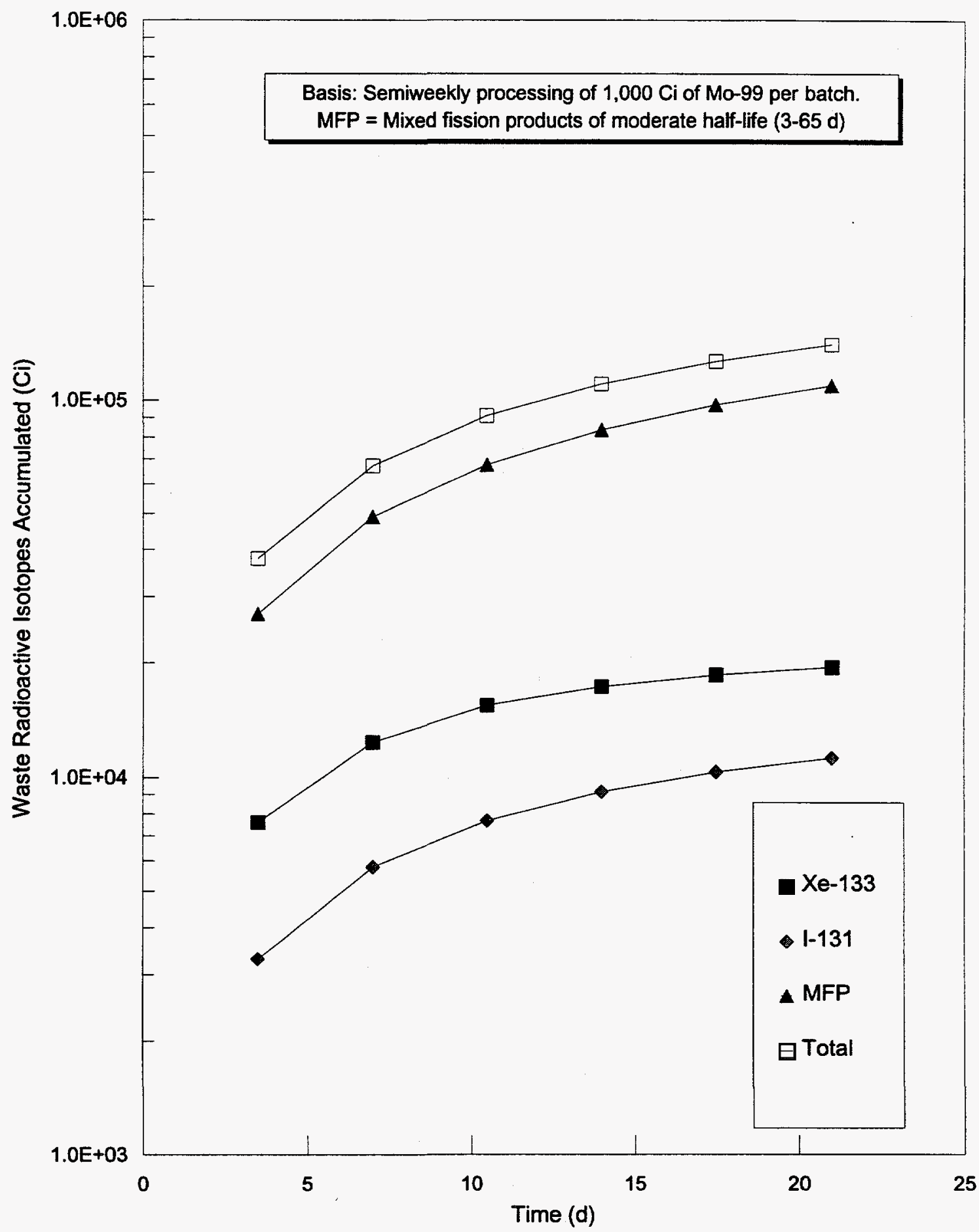

Fig. 1. Radioactive waste accumulation from Mo-F process. MFP $=$ mixed fission products. 
natural material. Since the postirradiation process is relatively simple, the target design can be optimized to reactor requirements; and different target designs can be used, if needed, to take advantage of different target positions in the same reactor. The target fabrication and testing are performed in nonradioactive environments.

In the case of ${ }^{99} \mathrm{Mo}-\mathrm{N}$ production, a higher flux generally translates into a higher production rate up to the point of saturation. The final specific activity achievable is also controlled by the available flux. Other factors influencing production rate include the neutron spectrum and the target design. Similarly to ${ }^{99} \mathrm{Mo}-\mathrm{F}$, targets must be accessible on demand to meet production schedules.

Processing of the ${ }^{99} \mathrm{Mo}-\mathrm{N}$ target after discharge from the reactor is simple and direct, requiring only removal of the material from the target, dissolution, and assay. Relatively light shielding is required for this process, and the absence of potential contaminants reduces the need for multiple work zones. An important aspect of ${ }^{99} \mathrm{Mo}-\mathrm{N}$ production is that it generates very little radioactive waste, and the radioactivity in this waste is short-lived.

\subsection{COMPARISON OF ${ }^{99} \mathrm{Mo}-\mathrm{F}$ AND ${ }^{99} \mathrm{Mo}-\mathrm{N}$}

From the standpoint of the producer, the primary differences between the two approaches are the relative simplicity of the ${ }^{99} \mathrm{Mo}-\mathrm{N}$ process and the virtual absence of radioactive waste from the ${ }^{99} \mathrm{Mo}-\mathrm{N}$ operation. Process simplicity translates into lower capital investment in facilities, reduced process time, lower process cost, and greatly reduced potential for interruption of operations. The waste situation may become increasingly significant in view of the current emphasis on control of waste, both by minimizing waste generation and by ensuring safe disposal of the waste that is generated. Not only the quantity, but also the type, of waste produced in the ${ }^{99} \mathrm{Mo}-\mathrm{F}$ process presents a problem. Many of the radioisotopes present in the waste are high-energy gamma emitters, which must be removed continuously from the system in order to maintain adequate shielding. Some radioisotopes, especially ${ }^{131} \mathrm{I}$ because of its volatility, require special handling both during and after separation. The presence of HEU also complicates the waste situation from the standpoints of accountability, criticality safety, safeguards, and nonproliferation of weapons materials.

The end result of using the two processes is the same-provision of carrier-free ${ }^{99 m} \mathrm{Tc}$ for synthesis of radiopharmaceuticals. The primary difference between the two products, ${ }^{99} \mathrm{Mo}-\mathrm{F}$ and ${ }^{99} \mathrm{Mo}-\mathrm{N}$, is the specific activity, which is $\sim 10^{4} \mathrm{Ci} / \mathrm{g}$ and $\sim 1$ to $150 \mathrm{Ci} / \mathrm{g}$, respectively. This difference leads to completely diverse approaches for distributing and handling the two products to achieve the same result. 
For the past 20 years, ${ }^{99} \mathrm{Mo}-\mathrm{F}$ has been the product of choice. The technology of all phases of ${ }^{99} \mathrm{Mo}-$ F production, distribution, and use is now well established, while the system employing ${ }^{99} \mathrm{Mo}-\mathrm{N}$ has disappeared in the United States and most developed countries, and is used in less-developed countries only when ${ }^{99} \mathrm{Mo}-\mathrm{F}$ is unavailable or when storage or disposal of radioactive waste cannot be accomplished. The possibility that the user community might convert back to ${ }^{99} \mathrm{Mo}-\mathrm{N}$, partially or totally, while adequate supplies of ${ }^{99} \mathrm{Mo}-\mathrm{F}$ were perceived to be available is remote unless a major improvement in ${ }^{99 \mathrm{~m}} \mathrm{Tc}$ concentration can be achieved. Therefore, ${ }^{99} \mathrm{Mo}-\mathrm{N}$ cannot now be considered as a supplement to existing supplies of ${ }^{99} \mathrm{Mo}-\mathrm{F}$, although it could be viewed as a replacement in case of longterm shortage of ${ }^{99} \mathrm{Mo}-\mathrm{F}$. Such a shortage would have to affect a major portion (or all) of the demand and would have to be of such duration as to justify the necessary change in technology at both the producer and the user level.

Opportunities exist to improve ${ }^{99} \mathrm{Mo}-\mathrm{N}$ technology, and any such improvement would have the effect of making the benefits of ${ }^{99} \mathrm{Mo}-\mathrm{N}$, especially as related to waste generation, nonproliferation, and environmental concerns, more significant. The major impediments to a change to ${ }^{99} \mathrm{Mo}-\mathrm{N}$ are the development of the required technology and the establishment of appropriate regulatory approvals. Technology development would have to precede regulatory approval, but both could be addressed in advance in order to minimize the impact on health care.

There are other bases, in addition to those noted above, on which ${ }^{99} \mathrm{Mo}-\mathrm{F}$ and ${ }^{99} \mathrm{Mo}-\mathrm{N}$ can be compared. Some areas or facilities will favor one process over the other in varying degrees, and some will be essentially neutral. An overall comparison is presented in Table 2 .

\section{POTENTIAL ORNL CONTRIBUTIONS}

\subsection{GENERAL}

If the DOE decides to take additional action (i.e., beyond the current initiative at SNL), ORNL could participate in several ways. These range from contingency planning to establishment of full-scale production capacity. The actual level, if any, of ORNL participation will depend on DOE's evaluation of risk and on the support available. Resources for both research/development activities and production can be provided at ORNL. 
Table 2. Overall comparison of ${ }^{99} \mathrm{Mo}-\mathrm{F}$ and ${ }^{99} \mathrm{Mo}-\mathrm{N}$ production/distribution systems

\begin{tabular}{|c|c|c|}
\hline Aspect & Characteristics of ${ }^{99} \mathrm{Mo}-\mathrm{F}$ & Characteristics of ${ }^{99} \mathrm{Mo}-\mathrm{N}$ \\
\hline \multicolumn{3}{|l|}{ Target Fabrication } \\
\hline Material & Highly enriched ${ }^{235} \mathrm{U}$ & Nonradioactive molybdenum \\
\hline Material availability & Currently available; questionable in future & Currently limited; increased production readily resumed \\
\hline Facility requirements & Full radiological capability; alpha control & Standard nonradiological laboratory \\
\hline Criticality & Control required & Not applicable \\
\hline Accountability & Full accountability required & Not required \\
\hline Technology & Established & General technique established; design required \\
\hline Nonproliferation safeguards & Required & Not required \\
\hline \multicolumn{3}{|l|}{ Reactor Irradiation } \\
\hline Flux required & Low to moderate & Moderate to high \\
\hline Space required & Low & Moderate \\
\hline Effect on reactor operation & Location dependent; may be significant & Insignificant \\
\hline Transport of irradiated target & $\begin{array}{l}\text { High heat/radiation load; cooldown period } \\
\text { required; container must be certified for fissile } \\
\text { material }\end{array}$ & $\begin{array}{l}\text { Insignificant heat load; modest radiation load; standard } \\
\text { radioactive material container; no cooldown period } \\
\text { required }\end{array}$ \\
\hline \multicolumn{3}{|l|}{ Process Facility } \\
\hline Radiological & $\begin{array}{l}\text { High beta-gamma shielding; alpha handling } \\
\text { capability; nuclear criticality controls }\end{array}$ & $\begin{array}{l}\text { Moderate beta-gamma shielding; no alpha; no criticality } \\
\text { concerns }\end{array}$ \\
\hline Work space & $\begin{array}{l}\text { Segregated work areas required for quality } \\
\text { control; waste handling space required }\end{array}$ & Less space; less segregation than ${ }^{99} \mathrm{Mo}-\mathrm{F}$; minimal waste \\
\hline Special equipment & $\begin{array}{l}{ }^{131} I \text { control; }{ }^{133} \mathrm{Xe} \text { fixation; unit shielding for } \\
\text { fresh targets and waste }\end{array}$ & None (process uses standard equipment) \\
\hline
\end{tabular}


Table 2 (continued)

\begin{tabular}{|c|c|c|}
\hline Aspect & Characteristics of ${ }^{99} \mathrm{Mo}-\mathrm{F}$ & Characteristics of ${ }^{99} \mathrm{Mo}-\mathrm{N}$ \\
\hline \multicolumn{3}{|l|}{ Process Chemistry } \\
\hline Complexity & $\begin{array}{l}\text { Multistage separation from mixed fission } \\
\text { products }\end{array}$ & None required; simple processes \\
\hline $\begin{array}{l}\text { Potential for product contami- } \\
\text { nation with other isotopes }\end{array}$ & $\begin{array}{l}\text { High; requires strict quality control and } \\
\text { segregation }\end{array}$ & None \\
\hline Criticality control & Required & Not applicable \\
\hline Accountability & Full accountability required & Not required \\
\hline Nonproliferation safeguards & Required & Not required \\
\hline Radioactive waste generation & $\begin{array}{l}\text { Very high amounts; complicated spectrum of } \\
\text { radioisotopes }\end{array}$ & Minimal; controlled by decay \\
\hline Radioactive waste packaging & $\begin{array}{l}\text { Waste must be removed continually; at least two } \\
\text { different streams; all is high level }\end{array}$ & $\begin{array}{l}\text { Minimal; low level; can be stored for convenience of } \\
\text { disposal }\end{array}$ \\
\hline Technology & Established & Established \\
\hline \multicolumn{3}{|l|}{ Product } \\
\hline FDA approval & Current & To be obtained \\
\hline Shipment methods & Established & To be developed; packages probably larger than ${ }^{99} \mathrm{Mo}-\mathrm{F}$ \\
\hline User handling procedures & Established & To be developed \\
\hline Recycle & Not required & Probably required to reduce cost of enriched ${ }^{98} \mathrm{Mo}$ \\
\hline
\end{tabular}




\subsubsection{Research and Development}

The technology for ${ }^{99} \mathrm{Mo}-\mathrm{F}$ production is well established, and any research and development (R\&D) related to it would be in the nature of process optimization. ORNL has not been directed by the DOE to provide R\&D support for the current initiative at SNL but could do so if the need should arise. If any of the ${ }^{99} \mathrm{Mo}-\mathrm{F}$ production options described below are undertaken at ORNL, R\&D would be required in the areas of target design and process chemistry. Such activities would be conducted concurrently with production system work and would be specific to the production system selected.

A large potential for $R \& D$ exists in the development of an efficient system for production, distribution, and use of ${ }^{99} \mathrm{Mo}-\mathrm{N}$. Work in this area would be completely independent of any work on ${ }^{99} \mathrm{Mo}-\mathrm{F}$. A research program leading ultimately to demonstration of a commercial-scale system for ${ }^{99} \mathrm{Mo}-$ $\mathrm{N}$ is presented in Sect. 7 .

\subsubsection{Production}

In 1991, at DOE's request, ORNL evaluated the establishment of large-scale ${ }^{99} \mathrm{Mo}-\mathrm{F}$ production by restarting the ORR, the $\mathrm{BSR}$, or both, and upgrading the RDL to a ${ }^{99} \mathrm{Mo}$ processing facility (Appendix A). This remains an option for DOE. Production of ${ }^{99} \mathrm{Mo}-\mathrm{F}$ in the HFIR has been considered only briefly in the past but could be evaluated in more detail. Production studies for ${ }^{99} \mathrm{Mo}-\mathrm{N}$ have been initiated at $\mathrm{ORNL}$, and early results indicate that this will be a viable consideration. The potential production of ${ }^{99} \mathrm{Mo}-\mathrm{F}$ and ${ }^{99} \mathrm{Mo}-\mathrm{N}$ is discussed in Sects. 6 and 7, respectively.

\subsection{RESOURCES AVAILABLE AT ORNL}

ORNL has a wide range of resources that could be applied to both investigative and productionoriented work on ${ }^{99} \mathrm{Mo}$. There is a sound base of expertise in all areas necessary for the work. In particular, ORNL's background as the major DOE source of reactor-produced radioisotopes for more than four decades provides experience in reactor operation, radiochemical processing, and associated areas of distribution and sales. The Research Reactors Division, the Isotope Technology Section of the Chemical Technology Division, and the Nuclear Medicine Group of the Health Sciences Research Division are currently engaged in the types of work needed. In addition to the direct participants, all necessary support such as engineering, quality assurance, analytical services, and others are readily available.

Facilities now available at ORNL could support the R\&D phase of a ${ }^{99}$ Mo program. Establishment of

${ }^{99} \mathrm{Mo}-\mathrm{F}$ production capability at ORNL would be a major undertaking, requiring $\sim 3$ years and $\$ 20$ million 
to accomplish (see Appendix A). Currrent developmental work indicates that a significant capacity for ${ }^{99} \mathrm{Mo}-\mathrm{N}$ production could be established at ORNL in a relatively short time with modest investment.

\section{POTENTIAL PRODUCTION OF ${ }^{99}$ Mo-F AT ORNL}

\subsection{ORR/BSR PRODUCTION}

Production of ${ }^{99} \mathrm{Mo}-\mathrm{F}$ at the levels presently contemplated by DOE could be accomplished by restarting the ORR as a dedicated facility. The BSR could also be restarted to serve as a backup production unit. Restart of the ORR was one of the proposals presented to DOE in 1991; however, it, among others, was rejected in favor of production at LANL. More recently, DOE has begun work to establish ${ }^{99} \mathrm{Mo-F}$ production at SNL. As part of this project, it is necessary to prepare an Environmental Impact Statement (EIS), which includes information on alternatives that have been considered.

In response to a request from the team preparing the EIS for the SNL production, ORNL reviewed, revised, and updated the previous ORNL proposal. The results were reported in a memorandum, which is reproduced in its entirety as Appendix $\mathrm{A}$. The time and cost required to establish full-scale production capability at ORNL are very similar to the SNL estimates. There is little question that ${ }^{99} \mathrm{Mo}-\mathrm{F}$ production could be established at ORNL. With this option, other benefits could also be realized by the research community through the production of additional isotopes. Of course, any considerations must be based on the position that the ORR/BSR system would be used for ${ }^{99} \mathrm{Mo}-\mathrm{F}$ production and any other operations would be strictly marginal.

\subsection{HFIR PRODUCTION}

\subsubsection{General Considerations}

The only reactor currently operating at ORNL, the HFIR, definitely has the potential for producing ${ }^{99} \mathrm{Mo}$ in commercial quantities (either ${ }^{99} \mathrm{Mo}-\mathrm{F}$ or ${ }^{99} \mathrm{Mo}-\mathrm{N}$ ). Even a cursory examination of the potential

${ }^{99} \mathrm{Mo}$ production indicates the capacity to generate far more material than necessary to satisfy known total needs. Modifications to the facility and/or the operating schedule would be required in order to utilize the HFIR. The physical plant modification described below could be done without significant effect on any current HFIR missions. Changes in operating schedule could, and probably would, influence other missions to some extent. 


\subsubsection{Modifications of the Physical Plant}

The high-flux interior target locations in the HFIR are not appropriate for ${ }^{99} \mathrm{Mo}-\mathrm{F}$ production because of the effects on reactivity and the problems associated with fission/gamma heating. Similar, but smaller, effects would apply to use of the innermost target positions in the current-design beryllium reflector (i.e., the RB- and CR-type positions); and these are frequently used for other purposes. Thus, only the vertical experiment facility (VXF) positions would be available for possible ${ }^{99} \mathrm{Mo}-\mathrm{F}$ production. These positions (1) have neutron flux levels that are at least double those used for ${ }^{99} \mathrm{Mo}-\mathrm{F}$ production at ORNL and other reactors in the past, (2) have relatively large target volume capacity, and (3) are situated such that reactivity and thermal effects would be minimal. Studies concerning possible modifications of the reflector beryllium are presently being conducted. Although such modifications might influence the exact target designs for ${ }^{99} \mathrm{Mo}-\mathrm{F}$, they would probably not significantly change the overall capacity.

The serious technical obstacle to use of the HFIR for ${ }^{99} \mathrm{Mo}-\mathrm{F}$ production is the fact that targets can be inserted or removed only during periods when the reactor is shut down, or approximately once per month. The user community could probably adapt schedules to accommodate regular shutdown periods, but availability only on a monthly basis would be a very severe impact on ${ }^{99} \mathrm{Mo}$ use. Adaptation of VXF positions for on-stream access, which was investigated a few years ago in connection with another project, appears to be feasible; the concept would apply to ${ }^{99} \mathrm{Mo}-\mathrm{F}$ targets or other isotope targets. The project was terminated before the design was completed, after considerable preliminary work had been accomplished. Essentially, the system involves installation of a thimble in a VXF position so that the interior of the thimble is isolated from the reactor coolant but open to the reactor pool. Interior design permits the target to be cooled by natural convection. With this arrangement, the target can be inserted and removed mechanically with no necessity for reactor shutdown. This system, which is simple in concept and relatively inexpensive, would provide irradiation capacity for ${ }^{99} \mathrm{Mo}-\mathrm{F}$ as well as for other isotopes where target volume and accessibility are more significant than flux.

\subsubsection{Adjustment of Schedule}

The HFIR operates on a cycle composed of an operational period followed by a shutdown. For a given cycle, the operating time is determined by fuel consumption, which depends on the power level and the reactivity effects of experiments and other reactor components. Refueling and maintenance are performed during shutdowns; and, above a certain minimum required for surveillance checks, the shutdown period is usually defined by the amount of maintenance required. Other circumstances such as unplanned outages and administrative actions can influence the schedule, but these are relatively 
infrequent. The current nominal cycle consists of a 26-d operational period and a 10-d shutdown, or about ten cycles per year. Without modification to permit target access during operation, such as described in Sect. 6.2 .2 above, ${ }^{99} \mathrm{Mo}-\mathrm{F}$ targets would be available only at the end of operating periods. Considering the essentially steady-state need for ${ }^{99} \mathrm{Mo}$ and its short half-life, such a situation is unlikely to be acceptable to the ${ }^{99}$ Mo user community.

The HFIR could be shut down and restarted during a cycle, but such a major perturbation in the schedule would adversely affect other missions and would increase costs. Rescheduling should be considered as a temporary measure rather than as a routine operation, but it could be utilized in cases of short-term loss of other reactor capacity.

Scheduling of HFIR operations specifically for ${ }^{99} \mathrm{Mo}-\mathrm{F}$ production would involve a compromise between the "need" schedule and the practical constraints on the HFIR. When the reactor is shut down, ingrowth of ${ }^{135} \mathrm{Xe}$ from decay of fission product ${ }^{135} \mathrm{I}$ in the reactor fuel produces a neutron poison effect that prevents restart until the ${ }^{135} \mathrm{Xe}$ has decayed. The decay period varies with conditions but is typically between 48 and $60 \mathrm{~h}$. There are also procedures and administrative controls on startup. Collectively, these constraints limit the ability to restart to a minimum of $2 \mathrm{~d}$, and maintenance requirements can extend this period. With some adaptation on the part of users, the ${ }^{99} \mathrm{Mo}$ need could probably be satisfied from HFIR by dividing the present 36-d cycle into three equal operational periods of $8 \mathrm{~d}$ each followed by a 4-d shutdown in each case. This is a simplification, and the actual possibility would depend on a number of factors that cannot be evaluated in advance.

\subsubsection{Other Requirements}

Use of the HFIR for ${ }^{99} \mathrm{Mo}-\mathrm{F}$ production requires that there be an acceptable, fully approved target design, and that the appropriate equipment and procedures for removal and transport of targets be available. Efficient use would also require that process capability be in place at ORNL; however, on-site processing is not an absolute requirement. In the past, ORNL produced ${ }^{99} \mathrm{Mo}-\mathrm{N}$ in the ORR and shipped the unprocessed material to private sites for processing. ORNL has also studied transport of ${ }^{99} \mathrm{Mo}-\mathrm{F}$ targets to other locations, although this has not actually been demonstrated. Transport of ${ }^{99} \mathrm{Mo}-\mathrm{F}$ targets from the HFIR to a processing site either within or outside of ORNL will require (1) qualified shipping containers capable of shielding the short-lived fission products, which are present in amounts far exceeding the ${ }^{99} \mathrm{Mo}$; and (2) approval for shipment of special nuclear material. 
The most important requirement for utilization of the HFIR is that the selected system be in place and ready for immediate implementation when needed. Even a few days' shortage of ${ }^{99} \mathrm{Mo}$ would present a serious problem, while a shortage lasting weeks or months would be disastrous to U.S. health care.

\subsection{PROCESS FACILITIES}

Operations for ${ }^{99} \mathrm{Mo}-\mathrm{F}$ production and distribution include target fabrication, reactor irradiation, processing, and shipment plus the necessary support for all of these. Support facilities are not addressed here except to state that ORNL has a full spectrum of auxiliary systems to provide any needed level of support. Likewise, ORNL has a fully operational radioactive material shipping operation already in place. Any impact on support and/or shipping systems resulting from ${ }^{99} \mathrm{Mo}-\mathrm{F}$ would be reflected in the need to increase staff and/or modify schedules, not in the facilities themselves. The two necessary facilities, in addition to reactors, which would have to be provided are those required for target fabrication and postirradiation processing (product recovery and waste disposal).

\subsubsection{Targets}

Either in-house target fabrication or outside procurement could be considered. Both approaches have merit, but the former is preferred and is recommended here. The primary reason for this is to maintain the production flexibility needed for a manufacturing operation with changing requirements. Local control and oversight of the rigid quality assurance for the targets are additional advantages. A dedicated facility for ${ }^{99} \mathrm{Mo}-\mathrm{F}$ targets provides the best assurance that production will not be compromised by other missions.

The specific design selected for the ${ }^{99} \mathrm{Mo}-\mathrm{F}$ target will define the required tooling and equipment, but some facility requirements will be common to all potential designs. The operation involves the handling of HEU in kilogram amounts. Therefore, criticality control and nuclear material security will be of paramount importance. Physically secure and subcritical safe storage and handling systems will be needed. Glove-box operations will be required for primary containment and atmosphere control. Secondary containment may be provided either by the building itself or by a separate system. Intrusion, criticality, and contamination alarms and controls will be necessary.

An area on the second floor of the RDL (Building 3047) could readily be converted into a target fabrication facility. It is adjacent to, but not directly connected to, the proposed processing area (see Sect. 6.3.2), with which it shares general building services. Secondary containment already exists, as do the services required for installation of glove boxes for primary containment. Proximity of the target 
fabrication facility to the operating area would offer the advantages of shared staff, supervision, and support.

\subsubsection{Processing}

Of the existing facilities at ORNL that might be considered for ${ }^{99} \mathrm{Mo}-\mathrm{F}$ processing, the four-cell line in the operating area of the RDL seems best suited in terms of capacity, shielding, and general characteristics. The RDL is currently operational and is expected to be so for the foreseeable future. It is equipped with all regular services for radiochemical operation, including secondary containment; thus, required modifications and equipment installation would be only those specific to ${ }^{99} \mathrm{Mo}-\mathrm{F}$. Very significantly, the basic safety documentation (SAR and OSR) is current, and the revisions necessary for ${ }^{99} \mathrm{Mo}-\mathrm{F}$ would be straightforward within the framework of currently approved operations.

The four RDL cells are connected in series by pass-throughs but can be isolated from each other, for individual access, via top plug, rear door, or, for the two end cells, remote "loadin" $\rho$ "loadout" blisters. The material flow pattern is very important for ${ }^{99} \mathrm{Mo}-\mathrm{F}$ processing because of the necessity of proceeding from the initial processing, which is highly contaminated with other fission products, to the final product, which must be essentially free of all radioactivity other than ${ }^{99} \mathrm{Mo}$. The basic operations in the four-cell line would be: (1) target receipt and initial dissolution, (2) separation of ${ }^{99} \mathrm{Mo}$ and waste recovery, (3) final purification of ${ }^{99} \mathrm{Mo}$, and (4) dispensing of products.

The specific equipment needed would depend on the chemical process, which, in turn, would depend on the target design. In general, provisions must be made for the control of fission gases, which would be evolved during target dissolution, and of ${ }^{131} \mathrm{I}$, which could be volatilized under certain conditions. In addition to the ${ }^{99} \mathrm{Mo}-\mathrm{F}$ process itself, the $\mathrm{HEU}$ and fission product waste processes would require specialized equipment.

Little modification of the RDL facility proper would be required for ${ }^{99} \mathrm{Mo}-\mathrm{F}$ processing, and the ${ }^{99} \mathrm{Mo}-$ $\mathrm{F}$ process capability and preparation for ${ }^{99} \mathrm{Mo}-\mathrm{F}$ production would not interfere with other RDL missions. However, if it should become necessary for $\mathrm{RDL}$ to be used for routine production of ${ }^{99} \mathrm{Mo}-\mathrm{F}$, all other missions would have to be terminated. Options such as part-time ${ }^{99} \mathrm{Mo}-\mathrm{F}$ processing or alternating ${ }^{99} \mathrm{Mo}-$ F processing with other work would not be feasible. This fact must be thoroughly understood and accepted at all levels in order for ${ }^{99} \mathrm{Mo-F}$ production at ORNL to be viable. 


\section{DEVELOPMENT OF ${ }^{99}$ Mo-N PRODUCTION SYSTEM}

\subsection{PURPOSE AND GOALS}

A system for production of ${ }^{99} \mathrm{Mo}-\mathrm{N}$ generators, delivery to user locations, and recovery of ${ }^{99 \mathrm{~m}} \mathrm{Tc}$ for use could provide many significant improvements relative to the current commercial production of ${ }^{99} \mathrm{Mo}-\mathrm{F}$. Such a system would have to satisfy certain criteria, as follows:

- The final products of the operation, the radiopharmaceutical agents, must be equal or superior to those produced by the ${ }^{99} \mathrm{Mo}-\mathrm{F}$ system in terms of radiochemical purity, chemical purity, concentration, and other acceptability factors.

- The ${ }^{99} \mathrm{Mo}-\mathrm{N}$ must be deliverable in a form that permits recovery of the ${ }^{99 \mathrm{~m}} \mathrm{Tc}$ and its conversion to final use form, using facilities and personnel normally available to a nuclear medicine practice.

- The ${ }^{99} \mathrm{Mo}-\mathrm{N}$ system must be fully approvable by the appropriate regulatory bodies.

- Availability must be amenable to the actual need schedule.

- The cost must be equal to, or less than, the ${ }^{99} \mathrm{Mo}-\mathrm{F}$ currently produced.

A plan for developing a ${ }^{99} \mathrm{Mo}-\mathrm{N}$ production and distribution system is outlined below. The phases are shown as sequential, but some could be carried out concurrently. The overall goal of this work would be to develop a system based on irradiation of ${ }^{98} \mathrm{Mo}$ that would provide ${ }^{99 \mathrm{~m}} \mathrm{Tc}$, fully approved for clinical use, in the amounts and on the schedule required to sustain the needs of nuclear medicine.

\subsection{DEVELOPMENT PLAN FOR ${ }^{99} \mathrm{Mo}-\mathrm{N}$}

\subsubsection{Preliminary Assessment}

The first phase of this project consists of literature review, contacts with current and former producers and users of ${ }^{99} \mathrm{Mo}-\mathrm{N}$, and assessment of the overall needs of the ${ }^{99 m} \mathrm{Tc}$ user community. Published information on ${ }^{99} \mathrm{Mo}-\mathrm{N}$ production is expected to be limited, but internal records of producers both within and without the DOE should yield some useful data. An important goal of this phase is to derive a "sense of the community" with respect to the level of concern, range of adaptability among users, real or perceived problems, and, in general, acceptability of the proposed new technology. Included in the results of this assessment will be determination of the relative needs, or preferences, among users for a generator-based, in-house supply of ${ }^{99 m} \mathrm{Tc}$ as compared with a supply of separated ${ }^{99 m} \mathrm{Tc}$ from a central location. Possible approaches to system design will be evaluated, and the most promising one(s) will be 
selected. Contacts will be established within the user community concerning future participation in evaluation of the system.

\subsubsection{Initial Experimental Work}

\subsubsection{Production Parameters}

Rates of production under various conditions will be determined. Basic data will be obtained from small, short-duration irradiations at high flux. The effects of chemical and physical form of target, target geometry, and flux variation will be investigated in larger-scale experiments. Of necessity, these experiments will be specific to the HFIR, but designs will be made as generalized as practical. The optimum chemical and physical forms and configurations for the target will be selected. In conjunction with the irradiation experiments, the possibility of modifying certain HFIR target positions for on-line access will be investigated.

The goal of this subtask will be to develop a reference target design that will produce ${ }^{99} \mathrm{Mo}$ of useful quality (i.e., specific activity) and quantity in the HFIR, with the potential of using identical or similar designs in other reactors.

\subsubsection{Process Chemistry}

Procedures will be developed for processing the irradiated target to a form suitable for loading the generator system. The types and levels of undesirable radionuclides in the irradiated fuel will be identified; and, if required, processes for their removal will be developed.

\subsubsection{System Chemistry}

As presently visualized, the needed end product of the ${ }^{99} \mathrm{Mo}-\mathrm{N}$ project is a generator assembly that will (1) sorb the ${ }^{99} \mathrm{Mo}$ onto a solid medium for transport, (2) allow the ${ }^{99 m} \mathrm{Tc}$ to be removed from the medium free of ${ }^{99} \mathrm{Mo}$, (3) concentrate the ${ }^{99 m} \mathrm{Tc}$, and (4) convert the ${ }^{99 m} \mathrm{Tc}$ to a chemical form suitable for synthesis of radiopharmaceutical agents. Other requirements are that the assembly be transportable and that it be operable by skilled nuclear medicine personnel. Experimental work will be performed to select the appropriate media and process chemicals, and to demonstrate their suitability for use. Methods of stripping the residual ${ }^{98} \mathrm{Mo}$ from the system will also be investigated. 


\subsection{SYSTEM DESIGN}

Results of the experimental work will lead to the design of one or more system(s) meeting the stated requirements. As used here, "system" refers to (1) the target design, (2) the process required to prepare the ${ }^{99} \mathrm{Mo}$ for generator loading, (3) the deliverable generator assembly design, (4) the process required to load the generator, (5) the process required to recover ${ }^{99 \mathrm{~m}} \mathrm{Tc}$ in usable form from the generator, and (6) procedures for handling the depleted generator. The overall system design will be based on irradiation in the HFIR and processing at ORNL, but adaptability to other facilities will be a consideration. Necessary QA/QC practices and other supportive requirements will be incorporated. Prototype hardware will be fabricated, tested, and modified if required. Sufficient evaluation, including fully radioactive tests, will be done to ensure that the system will function as designed.

\subsection{DEMONSTRATION}

Demonstration of the technology for ${ }^{99} \mathrm{Mo}-\mathrm{N}$ use will involve cooperative work between ORNL and one or more other organizations. The level of demonstration will depend on a number of factors, such as the decision by the DOE as to the extent of DOE participation in any actual commercial use of the ${ }^{99} \mathrm{Mo}-$ $\mathrm{N}$ system. The demonstration could simply consist of proving the technology and effecting its transfer to the private sector. It could involve DOE production of the ${ }^{99} \mathrm{Mo}-\mathrm{N}$ only, with secondary suppliers preparing and distributing the generators to end users. At the highest level of DOE involvement, the Department would provide generators directly to the end users. Each of these three possibilities would result in a different approach to the demonstration phase of this project. At the minimum, ORNL will prepare full-scale demonstration systems and provide them to selected organizations for evaluation and appropriate feedback.

\subsection{FACILITIES FOR ${ }^{99} \mathrm{Mo}-\mathrm{N}$}

Processing of ${ }^{99} \mathrm{Mo}-\mathrm{N}$ requires only moderate shielding and, relative to ${ }^{99} \mathrm{Mo}-\mathrm{F}$, limited work space. The actual needs will depend on the results of the experimental program described above. Preliminary evaluation based on limited past experience indicates that three separated work zones would probably be required-one for target opening and initial processing, one for generator assembly loading, and one for preparing the generator for shipment. Depending on the scale and complexity of the process, the first two operations could possibly be conducted in the same area, but at least two areas would be necessary. 
Establishment of ${ }^{99} \mathrm{Mo}-\mathrm{N}$ as a significant contributor to the overall ${ }^{99} \mathrm{Mo}$ supply system will probably require construction of dedicated process facilities. (These could be either government or commercial operations.) Compared with most radiochemical process facilities, those intended only for ${ }^{99} \mathrm{Mo}-\mathrm{N}$ processing would be predominantly standard industrial construction. Commercially available hot cells could be utilized, and waste disposal systems would be relatively simple. Eventually, two or more process sites would be necessary to ensure continuous production.

\subsection{AVAILABILITY OF TARGET MATERIAL}

\subsubsection{Amounts Required}

An important consideration in a system for ${ }^{99} \mathrm{Mo}-\mathrm{N}$ production is the availability of sufficient quantities of enriched ${ }^{98} \mathrm{Mo}$ target feedstock. The amounts needed to sustain a supply system will be defined by the production capacity and the fraction of the market that needs to be served. Both of these are unknown at present, but some approximations can be used for illustration and for scoping of the problem.

Based on preliminary data and calculations, production of ${ }^{99} \mathrm{Mo}-\mathrm{N}$ in the HFIR at a specific activity of $150 \mathrm{Ci} / \mathrm{g}$ at discharge does not appear to be an unrealistic goal. ${ }^{7}$ Assuming delivery of the generators to the customer $5 \mathrm{~d}$ after discharge, the amount of ${ }^{98}$ Mo needed to sustain the total estimated need of 4000 $\mathrm{Ci} /$ week would be $100 \mathrm{~g} /$ week. Fractional market share and/or higher specific activity would reduce this value, while lower specific activity would increase it.

\subsubsection{Current Supply}

The current sources of enriched ${ }^{98} \mathrm{Mo}$ are the calutrons at ORNL and those operated by the former Soviet Union. Neither is presently producing ${ }^{98} \mathrm{Mo}$, and their combined inventories are estimated to total about $2000 \mathrm{~g}$. ORNL has calutron units on standby, which could be restarted with a lead time of 6 months and would have an annual capacity of 2000 to $3000 \mathrm{~g}$. Other units now in shutdown condition could be reactivated with a longer lead time and, thereby, further increase output. Efficient use of targets, recycling of target material, and increased production of enriched ${ }^{98} \mathrm{Mo}$ will minimize the cost of target material. Target efficiency is basically a matter of optimization of target design and irradiation conditions in order to produce the highest practical specific activity. Recycling of target material is definitely a possibility and would be technically relatively simple. Both of these actions should be 
addressed in the development phase of the ${ }^{99} \mathrm{Mo}-\mathrm{N}$ project. The long-term solution to target material supply probably lies in enrichment of ${ }^{98} \mathrm{Mo}$ by an alternative process, plasma separation.

\subsubsection{Plasma Separation Process}

Establishment of DOE capability to enrich stable isotopes by the Plasma Separation Process (PSP) would be beneficial for ${ }^{98} \mathrm{Mo}$ as well as for many other stable isotopes. Relative to calutron separation, PSP has the advantage of high throughput but the general disadvantage of lower single-pass enrichment. However, the PSP prototype production machine now stored at ORNL has an estimated capacity to produce $100 \mathrm{~kg}$ of $92 \%{ }^{98}$ Mo per year.

\section{RECOMMENDATIONS}

The current and planned ${ }^{99}$ Mo production and distribution system has enough vulnerabilities to warrant serious consideration of additional efforts by DOE to mitigate the effects of an interruption in supply. Two essentially independent approaches are available: establishment of additional capacity for ${ }^{99} \mathrm{Mo}-\mathrm{F}$, and development of a system for ${ }^{99} \mathrm{Mo}-\mathrm{N}$. ORNL has the capability to address the problem by either approach, or by both, given the appropriate level of financial and administrative support.

Recognizing that available financial support will be limited, it is recommended here that priority be given to the development of ${ }^{99} \mathrm{Mo}-\mathrm{N}$ production as an alternative to, and possible replacement for, the present ${ }^{99} \mathrm{Mo}-\mathrm{F}$ system. The four primary reasons for this recommendation are as follows:

- Elimination of the need to use HEU will remove any concerns related to nuclear proliferation and will simplify both the target fabrication and processing operations.

- Development of a ${ }^{99} \mathrm{Mo}-\mathrm{N}$ system will remove one of the most serious vulnerabilities in ${ }^{99} \mathrm{Mo}$ supply - the problem of controlling and disposing of the large amounts of waste generated during ${ }^{99} \mathrm{Mo}-\mathrm{F}$ production.

- The cost and, especially, the time necessary to develop a viable ${ }^{99} \mathrm{Mo}-\mathrm{N}$ system will be significantly less than for a ${ }^{99} \mathrm{Mo}-\mathrm{F}$ system.

- Active experimental work on ${ }^{99} \mathrm{Mo}-\mathrm{N}$ could begin immediately upon project approval.

\section{1 ${ }^{99}$ Mo-F READINESS EVALUATION}

No direct work on the establishment of ${ }^{99} \mathrm{Mo}-\mathrm{F}$ capability at ORNL is recommended here; however, ORNL should be ready to respond immediately in the event that DOE efforts at SNL are terminated for 
any reason. The estimates presented in Appendix A should be updated at least annually. The status of the RDL should also be examined periodically with respect to its potential conversion for ${ }^{99} \mathrm{Mo}-\mathrm{F}$ processing.

An important aspect of the readiness posture is to ensure that both ORNL and DOE/ORO management are aware of the possibility that ORNL may be requested to undertake this project and are fully supportive of it. In such an event, there would be strong pressure for rapid and positive response.

\section{$8.2{ }^{99}$ Mo-N DEVELOPMENT}

Coordination and project management of the ${ }^{99} \mathrm{Mo}-\mathrm{N}$ effort at ORNL should be administered by the Isotope Technology Section, Chemical Technology Division, under the sponsorship of the DOE IPDP. The three main areas of investigation would be: (1) design and demonstration of an on-demand target insertion/discharge system for the HFIR; (2) preparation for increased production of enriched ${ }^{98} \mathrm{Mo}$; and (3) overall system development, including production yields, process chemistry, and design of the deliverable generator. The appropriate functional groups for these three subtasks are, respectively, the Technology Section of the Research Reactors Division, the Isotope Enrichment Facility of the Chemical Technology Division, and the Nuclear Medicine Group of the Health Sciences Research Division.

The precise levels and schedules for the various efforts are not addressed here. They will depend on the availability of support and the degree of urgency established by the DOE. By very rough approximation, the estimated costs and total times for the three main initial efforts are as shown below.

- Design, prototype fabrication, and demonstration of on-line target system for HFIR

Cost: $\$ 250,000$

Time: 12 months

- Preparation for startup of ${ }^{98}$ Mo production on calutron

Cost: $\$ 600,000$

Time: 6 months

- Development of ${ }^{99} \mathrm{Mo}-\mathrm{N}$ system through a full-scale demonstration (not including establishment of full production capability)

Cost: $\$ 120,000$

Time: 6 months 


\section{SUMMARY}

An adequate supply of ${ }^{99} \mathrm{Mo}$ is necessary for delivery of modern health care. Current sources of ${ }^{99} \mathrm{Mo}$, all of which are foreign, are subject to a number of vulnerabilities, which will become more pronounced with time. There is no potential for development of ${ }^{99} \mathrm{Mo}$ supply capability by the private industrial sector, and development of additional foreign capability sufficient to ensure an adequate supply is questionable. The only agent in a position to develop a domestic supply and, thus, to add substantially to the total capability, is DOE, which is currently pursuing such an initiative. Even if this initiative is successful, it is advisable to consider alternatives to the current ${ }^{99}$ Mo supply system.

ORNL has the resources and expertise to establish ${ }^{99} \mathrm{Mo}$ production capacity using current technology based on ${ }^{235} \mathrm{U}$ fission. This would require either restart of the ORR, and possibly also the BSR, or a major commitment of the HFIR. Either approach would be costly in terms of both money and time. In view of present budgetary constraints and other factors, it is unlikely that a major effort toward fission

production would be supported by DOE at this time; however, an alternative production method based on irradiation of ${ }^{98} \mathrm{Mo}$ can be investigated and potentially developed at significantly lower cost in a shorter time frame

Based on preliminary evaluation, it is quite possible that a production/distribution/use system based on irradiation of ${ }^{98}$ Mo could be developed, and that it could be made ready for immediate implementation in the event of interruption of ${ }^{99}$ Mo supplies from other sources. Such a system would eliminate a major vulnerability of the fission-based process - the control of large quantities of radioactive waste. Initial development would be conducted in three concurrent efforts: (1) HFIR target access, (2) increased production of enriched ${ }^{98} \mathrm{Mo}$, and (3) ${ }^{99} \mathrm{Mo}$ system development. Given an appropriate level of support from DOE, ORNL is in a position to initiate work on all three phases through a full-scale demonstration and to undertake production in the event that a shortage of this most critical medical radioisotope should develop.

\section{REFERENCES}

1. Independent Assessment of the DOE Plan to Establish a United States Production Source for Molybdenum-99, prepared by Jupiter Corporation for the USDOE, September 1994.

2. U.S. Department of Energy Isotope Production and Distribution Program Market Analysis Update, prepared by Arthur Andersen \& Co. for the USDOE, November 1994. 
3. Isotopes for Medicine and the Life Sciences, prepared by the Committee on Biomedical Isotopes, Institute of Medicine, National Academy Press, December 1994.

4. Study Report on the Department of Energy's Isotope Production and Distribution Program, prepared by the Senior Scientists and Engineers Committee, American Association for the Advancement of Science, for the Committee on Science, U.S. House of Representatives, February 1995.

5. Nordion International of Canada, press release dated November 10, 1995.

6. "The Future Supply of Molybdenum-99," J. Nucl. Med. 36(11), 15N (1995).

7. Saed Mirzadeh, ORNL, private communication, December 1995. 
Appendix A

MEMORANDUM FROM W. E. HILL TO R. L. STOVER, DATED AUGUST 17, 1995 



$\begin{array}{ll}\text { Date: } & \text { August 17. } 1995 \\ \text { To: } & \text { R. L. Stover } \\ \text { cc: } & \text { B. R. Appleton. W. K. Brown. R. D. Childs. E. D. Collins. G. F. Flanagan. } \\ & \text { H. A. Glovier, J. B. Richard. C. D. West. P. M. Whaley, RRD-DCC-RC } \\ \text { From: } & \text { W. E. Hill. 7917. MS 6399. 4-1554 }\end{array}$

Subject: Responses to Environmental Impact Statement (EIS) Concerving Mo-99 Production Utilizing Oak Ridge Reactor (ORR) and/or Bulk Shielding Reactor (BSR)

Pacific Northwest Laboratory (PNL) was tasked with the responsibility of preparing the subject EIS for Mo-99 production. I primarily dealt with Leonard Hustus of PNL and Mike Gavini of IR\&G. a PNL sub-contractor. Mike was tasked with preparing the technical responses and Leonard with preparing the environmental-related responses. Mike requested that I prepare and FAX him the responses to the generation facility questions in the EIS (Attachment 1). This action was completed on August 9, 1995 (Attachment 2). Mike and Leonard both requested cost estimates for operation: Mike requested cost estimates to resume operations. Both of these estimates were delivered by the requested dates (Emory Collins supplied all target preparation and target processing costs). Mike Gavini stated several times that he was going to do a fair evaluation based on each sites' technical capabilities.

The ORR cost estimates are based on ORR being restarted as a $10 \mathrm{MW}$ Class-B medical isotope production reactor (the ORR would not be renamed MIPC). The ORR's primary fuel would be low enriched uranium (LEU); however. 37 highly enriched uranium (HEU) elements and 7 HEU shim rods are still in storage@ $\mathrm{Y}-12$ and should be utilized if at all possible. The operating cycle would be greater than 60 days; refueling and restart could occur in $<12$ hours. Shifts would consist of four shifts of one supervisor and two operators/shift. Staffing would consist of three operations engineers. three engineering analysts. one design engineer, and two trainers. Additional staff would be funded for compliance, quality assurance. maintenance and health physics related tasks. The projected. burdened operating budget for ORR would be $\$ 5.5$ millionyear (in FY 1995 \$) and employ 37 FTEs. Hot cell costs are estimated @ \$4 million/year (Attachment 3). With this level of funding and $90 \%$ availability, ORR could produce $100 \%$ of the US Mo-99 requirements. ORR would utilize either HFIR or BSR as a backup.

The cost estimate assumed the ORR primary flow system would be relocated to the ORR basement. Three high density. plate-type $5 \mathrm{MW}$ heat exchangers and two $5,000 \mathrm{gpm}$ pumps would be purchased and installed in cells south of the pipe chase in the ORR's basement. The ORR secondary ( $30 \mathrm{MW}$ cooling tower) cooling lines would be extended to the basement to connect with the new heat exchangers. All new installation and major construction tasks were costed assuming engineering and MK Ferguson would do the work. ORR restart was assumed to require 30 months. 
R. L. Stover

August 17. 1995

Page 2

Some of the largest cost drivers for restart of the ORR are a new Safety Analysis Report $(\$ 1,000.000)$, new beryllium reflector pieces $(\$ 1.250 .000$ - old ones were broken up and discarded), and new holddown arms ( $\$ 300.000$ - old ones were discarded).

The biggest potential problem with the proposed operation is the requirement to pull Mo-99 samples 6 days a week. This would require a "quick-change", probably 6 days a week. "Quick changes" involve pre-staging targets and tools. scramming the reactor, turning off the flow, pulling the vessel top, changing out a target. buttoning up the vessel, starting up flow, and restaring the reactor. In the past. "quick changes" have been accomplished in $<20$ minutes. This method of operation is possible, but would be awkward. We should engineer our way out of it, if possible. An additional selling point for the ORR are its 6 beam lines and two large facilities. Researchers do not pay for beam time in the US: however. neutron beams in the US are over-subscribed and these beams would be put to instant use according to the researchers I spoke with.

The BSR cost estimates are based on the BSR being restarted and operated at $2 \mathrm{MW}$ in its current configuration using LEU fuel. BSR operation could be resumed in 24 months. The BSR systems require very few modifications; however, the BSR has more vuinerabilities. The BSR primary lines are buried outside of the building; primary coolant could be released directly to the environment if a leak developed. The air activity in the BSR high bay at full power was a hindrance in 1986, today it would probably require remediation. Problems could also be encountered with bridge access during full power (radiation fields are $>100 \mathrm{mr} / \mathrm{hr}$ ) and core boiling due to flow blockage. Pool water entering the core is not filtered prior to encountering the fuel. It was common in 1986 and before for specks the size of a dime to get caught on top of an element and remain there. Finally, the BSR was seldom operated from the BSR control room; radiation levels in the BSR control room would need to be looked at as the primary coolant lines run directly underneath the control room floor.

The biggest cost drivers for restart of the BSR are the Safety Analysis Report $(\$ 500,000)$ and fabrication of LEU fuel $(\$ 720.000)$. The BSR would require the same shift crew as the ORR; however, management and support would be less. The BSR's projected operating budget would be $\$ 3.5$ million (in FY 1995 \$) with 25.5 FTEs. Mo-99 target changeout would be much simpler due to the openness of the BSR core. Mo-99 production at BSR would supply approximately $40 \%$ of US needs. Sandia's Annular Core Research Reactor (ACRR), ORNL's primary competitor for this work, operates at the same power as the BSR, but has higher flux in the target region. The ACRR will produce $100 \%$ of the US needs. and is also being evaluated for an increase in power to $4 \mathrm{MW}$. Gavini stated that BSR's only realistic use was as a backup to the ORR. An additional obstacle to restart of the BSR from Gavini's perspective was it's use of HEU fuel (the cost estimate includes 48 new LEU elements). Gavini stated that only LEU fueled reactors will be restarted for Mo-99 production. Gavini also realized the ACRR could do a better job than BSR of making Mo-99 and asked if BSR could be doubled in power to $4 \mathrm{MW}$ or be converted to a TRIGA reactor. Power could be doubled if the heat exchanger was replaced. The current heat exchanger is rated at $2 \mathrm{MW}$. The cooling tower is rated at $5 \mathrm{MW}$. An increase in BSR power was not included in the BSR cost estimates. I did not believe conversion of the BSR to a TRIGA core to be a feasible or realistic alternative (DOE already has a 2 MW TRIGA reactor @ Sandia). 
R. L. Stover

August 17. 1995

Page 3

Leonard and Mike consistently stated that ORNL's ORR/BSR had moved up to the top grouping of proposed Mo-99 production sites. They also stated HFIR had moved from the top grouping to the bottom grouping. Mike thought our strengths were restart of a medium-flux LEU reactor (ORR) coupled with a reliable backup (HFIR). Leonard stated our strength was ORNL's "complete package", i.e., we can do everything here. Sandia must rely on Los Alamos for target preparation. Additionally, the ACRR is a TRIGA reactor and is currently using 35\% fuel (not LEU), but has plans to reduce to LEU. According to Rodney Knight, General Atomics, who makes TRIGA fuel. was recently bought by CERCA. TRIGA fuel will. in all likelihood. be manufactured in France. ORR and BSR elements would be made at Babcock \& Wilcox in Lynchburg, Va.

In summation, cost estimates for restart and operation of the ORR and BSR were prepared and submitted for the purpose of resuming Mo-99 production at ORNL. Using the ORR as the primary source of Mo-99 production and the HFIR/BSR as a backup. ORNL has a good possibility of being rated at or near the top, technically, as a result of the EIS process.

WEH:ph 
Attachment 1

EIS EOR MEDICAL ISOTOPE PROJECT

SITE EVALUATION FORM

Page 2 of 6

\section{II. ${ }^{29}$ Mo GENERATION FACULTTY}

This project requires a $\geq 1 \mathrm{MW}$ nuclear reactor operating 6 days a week in a continuous mode which can provide thermal flux of no less than $10^{13}$ neutrons $/ \mathrm{cm}^{2}$. sec. and a aggregate target power of $400 \mathrm{KW}$. Facility should equipment to handle target insertion and retrieval with out disrupting the operation of the reactor and with minimal impact to the environment and to the heaith and safety of people. Outage time should be $\leq 6$ days to ensure continual production of

${ }^{\mathrm{M}} \mathrm{Mo}$. Ideally the target irradiation facility should be adjacent to the processing facility.

\section{SITE INFORMATION}

1. Reactor type:

2. Power level (MWt):

3. Status: Operational $\square \quad$ Not operational $\square \quad$ Feasibility and time to bring it back to operation:

4. Need for enhancement of the reactor - feasibility and time required:

5. Fuel : \% Uranium Enrichment:

Equivalent Availability Factor:

6. Frequency of refueling: Outage time (days):

Need and feasibility of core replacement:

7. Source of reload fuel:

8. Past record of refueling or core modifications:

9. Past reactor performance Record:

10. Feasibility of unfissioned $U^{235}$ recovery on site: 


\section{EIS FOR MEDICALISOTOPEPROJECT} SITE EVALUATIJN FORM

\section{II. ${ }^{92}$ Mo GENERATION FACILJTY(continued)}

11. No. of target bays available: Target power level: Total power level:

Thermal neutron flux at the target: (Neutrons $/ \mathrm{cm}^{2}$. second)

12. Ease of target movement in and out of the reactor without interrupting the reactor operations

13. Anticipated curie content of the target after irradiation:

14. No. of DOT approved casks availability:

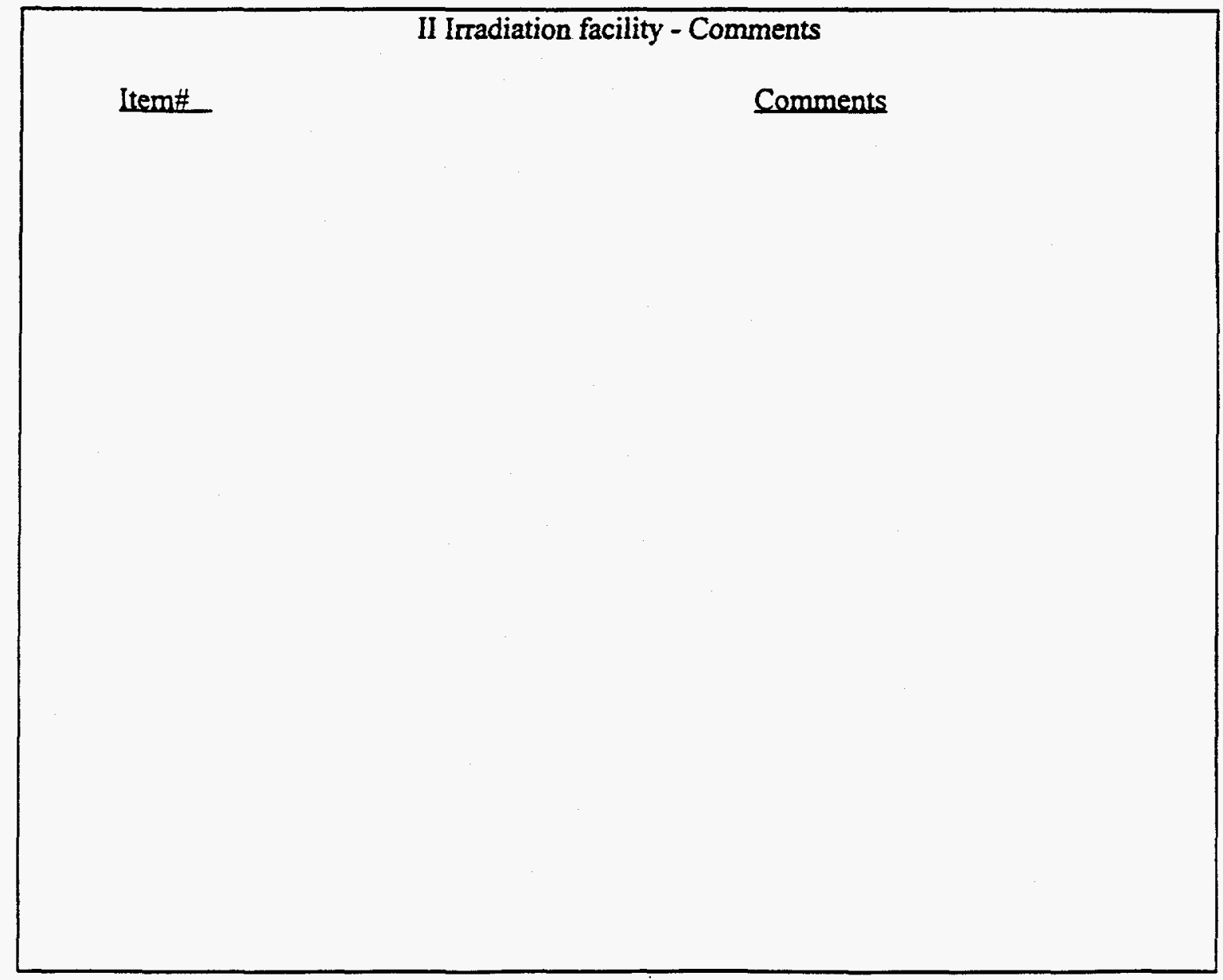


Attachment 2

Mo-99 Generation Facility Responses for ORR

Reactor is a tank type.

Power will be $10 \mathrm{MW}(\mathrm{t})$.

Reactor is not operational. Time to restart estimated at 30 months. Costs and schedule in preparation. Restart is very feasible.

Enhancements would include moving pumps, heat exchangers and supporting primary components into reactor building and installing new resin slurry system. Is feasible; time required will be 30 months.

Fuel will be MTR-type 20\% LEU fuel. ORR was test reactor for LEU development program.

Equivalent availability factor-at $10 \mathrm{MW}$, the ORR cycle between refuelings will be $>60$ days long. Typical outages in the past at $30 \mathrm{MW}$ were $2-3$ days. Expect $10-\mathrm{MW}$ ORR will have $>90 \%$ availability.

Frequency of refueling will be every $60-80$ days. Outage time will vary from $12 \mathrm{~h}$ to $2-3$ days, depending on maintenance and surveillance work load. ORR has 32 LEU elements stored at the BSR and available for use. Six LEU shim rods will need to be fabricated, as will several spare cores. ORR had $\$ 1,000,000$ worth of new HEU fuel on hand when it was shut down. This fuel was nearly all declared scrap, and much of it was reprocessed. Seven HEU shim rods and 37 HEU elements still remain in storage at Y-12. Very feasible to do; fuel will be made in U.S. Potential problem in retrieving uranium from Y-12 Plant.

Source of reload fuel will be fuel in storage or new fuel. Very few core modifications have been made at ORR. Reactor was previously licensed for 30-MW operation. Refueling records are extensive; no major refueling problems are expected due to the extensive experience of refueling at the facility.

ORR has been a proven workhorse. Availability was $80 \%$ or greater over the reactor's life. The biggest problem the ORR experienced over its lifetime was primary coolant leaks outside the reactor building. This will not be a problem since the primary coolant system is being relocated inside the reactor building.

Unfissioned U-235 recovery from the fuel is not possible at ORNL. All spent fuel is shipped to Savannah River for reprocessing/storage.

ORR will irradiate up to ten target assemblies per week and adjust the target loading and target number/assembly to produce a total power level of $600 \mathrm{~kW}$. Thermal neutron flux in the ORR grid is 1.0 E14 neutrons $\mathrm{cm}^{-2} \mathrm{sec}^{-1}$.

Targets can be removed using a "quick change" procedure. Will require daily reactor shutdowns approximately six times per week to remove and replace targets.

Weekly curie content of the targets will be up to $35,000 \mathrm{Ci}$ immediately after irradiation. Activity of ${ }^{99} \mathrm{Mo}$ six days and 10 days after irradiation will be approximately 7000 and $2800 \mathrm{Ci}$, respectively. 
ORNL procured and owns an NRC-licensed GE-2000 cask.

The neutron science community could potentially be a benefactor due to the ORR's six beam tubes and two large facilities. These neutron facilities have been used for neutron-scattering experiments in the past and would be of immediate benefit to researchers since beam tubes in the United States are currently oversubscribed. Production of ${ }^{99} \mathrm{Mo}$ would be the ORR's primary mission, however.

The ORR pool has storage space for 180 elements. Four core loadings ( 96 elements) will be kept in storage, which will leave space for 84 spent fuel elements. At $90 \%$ availability, ORR will generate 22 spent fuel elements/year. At this rate of discharge, the ORR pool is adequate for approximately four operational years of storage. If relocation of spent fuel to Savannah River is not an option, additional storage space for approximately 900 ORR fuel elements (41 years' worth) is available in the BSR pool. Most of current BSR surveillance and maintenance costs are personnel related. If storage of ORR elements at the BSR becomes necessary, ORR staff could assume BSR surveillance and maintenance responsibilities at a nominal cost to the ORR budget. 


\section{Mo-99 Generation Facility Responses for BSR}

Reactor is a pool type.

Power will be $2 \mathrm{MW}(\mathrm{t})$.

Reactor is not operational. Time to restart estimated at 24 months. Restart is very feasible.

Enhancements would include installing a new resin slurry system. Cost sheet in preparation. Is feasible; time required will be 24 months.

Fuel will be MTR-type 20\% LEU fuel; however, BSR has 30 HEU elements and 6 shim rod elements in storage which should be considered for short-term use.

Equivalent availability factor-at $2 \mathrm{MW}$ the BSR cycle will be approximately 30 days long. Typical outages in the past were $2-3$ days. Expect BSR will have $>90 \%$ availability.

Frequency of refueling will be every 25-30 days. Outage time will vary from $12 \mathrm{~h}$ to $2-3$ days, depending on maintenance and surveillance work load. BSR has $30 \mathrm{HEU}$ elements stored at the BSR and available for use. Six HEU shim rod elements are available. LEU elements must be fabricated. Very feasible to do; fuel will be made in U.S. Potential problem retrieving uranium from Y-12 Plant.

Source of reload fuel will be fuel in storage or new fuel.

Significant core modification was made in the 1960 s when BSR went from natural circulation to forced circulation. Refueling records are extensive; no major refueling problems are expected due to the extensive experience of refueling at the facility.

Availability data are biased as BSR was run on demand. Demand was generally low in the 1970 s and 1980s. Predictability data not available.

Unfissioned U-235 recovery from the fuel is not possible at ORNL. All spent fuel is shipped to Savannah River for reprocessing/storage.

BSR will irradiate up to 12 target assemblies per week and adjust the target loading and target number/assembly to produce a total power level of $380 \mathrm{~kW}$. Average thermal neutron flux in the BSR grid, when it is set up for ${ }^{99} \mathrm{Mo}$ production, will be $1.1 \mathrm{E} 13$ neutrons $\mathrm{cm}^{-2} \mathrm{sec}^{-1}$.

Targets can be removed using a "quick change" procedure. Will require daily reactor shutdowns approximately six times per week to remove and replace targets.

Weekly curie content of the targets will be up to $3200 \mathrm{Ci} 6$ days after irradiation.

ORNL procured and owns an NRC-licensed GE-2000 cask. 
TOTAL COSTS

Mo-99 Production at ORNL

\begin{tabular}{|c|c|c|c|c|c|}
\hline Facility & FY -96 & FY-97 & FY-98 & $\begin{array}{c}\text { Construction \& } \\
\text { Engineering }\end{array}$ & Totals \\
\hline Reactor - ORR & 7070 & 6332 & 7022 & 2390 & 22813 \\
\hline Reactor - BSR & 3208 & 4195 & 4237 & 120 & 11760 \\
\hline Target Fabrication Facility & 530 & & & & 530 \\
\hline Process Facility & 800 & 1610 & & & 2410 \\
\hline \multicolumn{6}{|l|}{$\begin{array}{c}\text { Startup, Testing, Product } \\
\text { Evaluation }\end{array}$} \\
\hline \multicolumn{6}{|l|}{ ORR -Included under Reactor } \\
\hline \multicolumn{6}{|l|}{ BSR - Included under Reactor } \\
\hline Target Facility & & 100 & & & 100 \\
\hline Process Facility & & & 700 & & 700 \\
\hline $\begin{array}{l}\text { Restart Costs - ORR Irradiation + } \\
\text { Target Prep + Target Processing }\end{array}$ & 8400 & 8042 & 7722 & 2390 & 26553 \\
\hline $\begin{array}{l}\text { Restart Costs - BSR Irradiation + } \\
\text { Target Prep + Target Irradiation }\end{array}$ & 4538 & 5905 & 4937 & 120 & 15500 \\
\hline \multicolumn{6}{|l|}{ Decommissioning } \\
\hline ORR & & & & & 1000 \\
\hline BSR & & & & & 500 \\
\hline Target Facility & & & & & 250 \\
\hline Process Facility & & & & & 1250 \\
\hline \multicolumn{6}{|l|}{$\begin{array}{l}\text { Annual Operational Costs After } \\
\text { Restart (In FY-95 \$) }\end{array}$} \\
\hline ORR & & & & & 5571 \\
\hline BSR & & & & & 3538 \\
\hline $\begin{array}{c}\text { Target Prep \& Irradiated Target } \\
\text { Processing }\end{array}$ & & & & & 4018 \\
\hline
\end{tabular}


Restart Costs for ORR

$(x \$ 1000)$

\begin{tabular}{|c|c|c|c|c|c|}
\hline Restart Area & Item & $\begin{array}{c}\text { Estimated Costs } \\
\text { First Year } \\
\text { (Restart) } \\
\end{array}$ & $\begin{array}{l}\text { Estimated Costs } \\
\text { Second Year } \\
\text { (Restart) }\end{array}$ & $\begin{array}{l}\text { Estimated Costs } \\
\text { Third Year (Restart } \\
\text { \& Operation) }\end{array}$ & $\begin{array}{c}\text { Cost for } \\
\text { Construction \& } \\
\text { Engineeering }\end{array}$ \\
\hline \multirow[t]{2}{*}{ Personnel } & Restart & 1868.00 & 3800.68 & & \\
\hline & Operations & 0.00 & 0.00 & 4442.51 & \\
\hline \multirow[t]{2}{*}{$\begin{array}{c}\text { Readiness } \\
\text { Review }\end{array}$} & ORNL & 0.00 & 150.00 & & \\
\hline & DOE & 0.00 & 75.00 & & \\
\hline \multirow[t]{13}{*}{$\begin{array}{c}\text { Mechanical } \\
\text { Systems }\end{array}$} & $\begin{array}{c}\text { Test, Calibrate \& Repair all } \\
\text { Required Systems }\end{array}$ & 150.00 & 150.00 & 50.00 & \\
\hline & Primary Pumps (new) & 70.00 & 30.00 & 35.00 & 200 \\
\hline & $\begin{array}{l}\text { Primary to Secondary Heat } \\
\text { Exchangers (new) }\end{array}$ & 750.00 & 0.00 & & 1500 \\
\hline & Valves, Strainer, \& Piping & 100.00 & 50.00 & & 300 \\
\hline & $\begin{array}{l}\text { Restore Control Room } \\
\text { Functionality }\end{array}$ & 100.00 & 100.00 & & \\
\hline & Fabricate Reflector Pieces & 750.00 & 500.00 & & \\
\hline & Fabricate New Fuel Tools & 40.00 & 40.00 & & \\
\hline & Fabricate Hold-down Arms & 150.00 & 150.00 & & \\
\hline & $\begin{array}{l}\text { Install New Resin Slurry } \\
\text { System }\end{array}$ & 60.00 & 60.00 & & 240 \\
\hline & Install New Batteries & 0.00 & 5.00 & & \\
\hline & $\begin{array}{l}\text { Connect Heat Exchangers to } \\
\text { Secondary }\end{array}$ & 50.00 & 25.00 & & 150 \\
\hline & $\begin{array}{l}\text { Install New Acid Pumps for } \\
\text { Secondary }\end{array}$ & 0.00 & 10.00 & & \\
\hline & $\begin{array}{l}\text { Install New Filters in Cell } \\
\text { Vent \& Off-Gas Systems }\end{array}$ & 15.00 & 15.00 & & \\
\hline \multirow[t]{3}{*}{ Fuel (all LEU) } & Fuel Elements ( 32 on-hand) & 720.00 & 0.00 & 360.00 & \\
\hline & Shim Rods & 120.00 & 40.00 & 40.00 & \\
\hline & Fuel Racks & 45.00 & 30.00 & & \\
\hline \multirow[t]{6}{*}{ Documentation } & NEPA (Covered by EIS) & 0.00 & 0.00 & 0.00 & \\
\hline & SAR \& TSRs & 1000.00 & 0.00 & 0.00 & \\
\hline & NCSES \& NCSAs & 0.00 & 60.00 & 50.00 & \\
\hline & Procedures & 75.00 & 130.00 & 0.00 & \\
\hline & Drawings & 35.00 & 35.00 & 0.00 & \\
\hline & FFA Compliance & 50.00 & 50.00 & 0.00 & \\
\hline SUM This Sheet & & 6148.00 & 5505.68 & 4977.51 & \\
\hline $\begin{array}{c}\text { Misc. } \\
\text { Operational } \\
\text { Expenses }\end{array}$ & & & & 1128.36 & \\
\hline Contingency & $(15 \%)$ & 922.20 & 825.85 & 915.88 & \\
\hline $\begin{array}{c}\text { Sub-Total by } \\
\text { Year }\end{array}$ & & 7070.20 & 6331.53 & 7021.76 & 2390.00 \\
\hline $\begin{array}{c}\text { TOTAL COSTs } \\
\text { RESTART Year } \\
1-3\end{array}$ & $\begin{array}{l}\text { Assume MK Ferguson and } \\
\text { Engineering Involvement }\end{array}$ & & & 22813.49 & \\
\hline
\end{tabular}


ORR Costs for Personnel

\begin{tabular}{|c|c|c|c|c|c|c|c|}
\hline Work Area & $\begin{array}{c}\text { Charge rate (x \$1000) } \\
\text { Burdened. Escalated * } \\
\text { 1.04/year after Year 1 }\end{array}$ & $\begin{array}{c}\text { FTEs Year } \\
\text { 1-Restart }\end{array}$ & Year 1 \$ & $\begin{array}{c}\text { FTEs Year 2 - } \\
\text { Restar }\end{array}$ & Year 2 \$ & $\begin{array}{c}\text { FTEs Year 3 - } \\
\text { Operation }\end{array}$ & Year 3\$ \\
\hline $\begin{array}{c}\text { Facility } \\
\text { Management }\end{array}$ & 130.00 & 1.50 & 195.00 & 2.50 & 338.00 & 3.00 & 421.82 \\
\hline $\begin{array}{c}\text { Admin } \\
\text { Suppor }\end{array}$ & 45.00 & 0.50 & 22.50 & 1.00 & 46.80 & 1.00 & 48.67 \\
\hline Compliance & 136.00 & 0.50 & 68.00 & 0.50 & 70.72 & 0.50 & 73.55 \\
\hline $\begin{array}{c}\text { Engineering } \\
\text { Design }\end{array}$ & 117.00 & 1.00 & 117.00 & 1.00 & 121.68 & 1.00 & 126.55 \\
\hline $\begin{array}{c}\text { Engineering } \\
\text { Analysis }\end{array}$ & 170.00 & 2.00 & 340.00 & 2.00 & 353.60 & 3.00 & 551.62 \\
\hline Training & 72.00 & 0.50 & 36.00 & 2.00 & 149.76 & 2.00 & 155.75 \\
\hline QA & 103.00 & 0.50 & 51.50 & 0.50 & 53.56 & 0.50 & 55.70 \\
\hline SROs & 110.00 & 1.00 & 110.00 & 5.00 & 572.00 & 5.00 & 594.88 \\
\hline ROs & 96.00 & 2.00 & 192.00 & 10.00 & 998.40 & 10.00 & 1038.34 \\
\hline Maint & 109.00 & 4.00 & 436.00 & 6.00 & 680.16 & 8.00 & 943.16 \\
\hline HPs & 100.00 & 2.00 & 200.00 & 3.00 & 312.00 & 3.00 & 324.48 \\
\hline Security & 100 (fixed cost) & Fixed cost & 100.00 & Fixed cost & 104.00 & Fixed cost & 108.00 \\
\hline TOTALS & & 15.50 & 1868.00 & 33.50 & 3800.68 & 37.00 & 4442.51 \\
\hline
\end{tabular}


Restart Costs for BSR

(x $\$ 1000)$

\begin{tabular}{|c|c|c|c|c|c|}
\hline Restan Area & Item & $\begin{array}{l}\text { Estimated Costs } \\
\text { First Year } \\
\text { (Restart) }\end{array}$ & $\begin{array}{c}\text { Estimated Costs Second } \\
\text { Year (Restart) }\end{array}$ & $\begin{array}{c}\text { Estimated Costs Third } \\
\text { Year (Operation) }\end{array}$ & $\begin{array}{c}\text { Cost for } \\
\text { Construction } \\
\& \\
\text { Engineering }\end{array}$ \\
\hline \multirow[t]{2}{*}{ Personnel } & Restart & 1383.25 & 2785.48 & & \\
\hline & Operations & & & 2991.65 & \\
\hline \multirow[t]{2}{*}{ Readiness Review } & ORNL & & 150.00 & & \\
\hline & DOE & & 75.00 & & \\
\hline \multirow[t]{4}{*}{$\begin{array}{l}\text { Mechanical } \\
\text { Systems }\end{array}$} & \begin{tabular}{|c|} 
Test, Calibrate \& \\
Repair all \\
Required Systems
\end{tabular} & 110.00 & 70.00 & & \\
\hline & \begin{tabular}{|c|} 
Install New Acid \\
Pumps for \\
Secondary
\end{tabular} & 0.00 & 10.00 & & \\
\hline & $\begin{array}{c}\text { Install New } \\
\text { Filters in Cell } \\
\text { Vent \& Off-Gas }\end{array}$ & 15.00 & 15.00 & & \\
\hline & \begin{tabular}{|c|} 
Install New Resin \\
Slurry System \\
\end{tabular} & 30.00 & 30.00 & & 120.00 \\
\hline \multirow[t]{3}{*}{ Fuel (all LEU) } & Fuel Elements & 480.00 & 240.00 & 75.00 & \\
\hline & Shim Rods & 66.00 & 22.00 & 22.00 & \\
\hline & Fuel Racks & 45.00 & 30.00 & & \\
\hline \multirow[t]{6}{*}{ Documentation } & $\begin{array}{c}\text { NEPA (Covered } \\
\text { by EIS) }\end{array}$ & 0.00 & 0.00 & 0.00 & \\
\hline & SAR \& TSRS & 500.00 & 0.00 & 0.00 & \\
\hline & NCSEs \& NCSAs & 0.00 & 60.00 & 50.00 & \\
\hline & Procedures & 75.00 & 75.00 & 0.00 & \\
\hline & Drawings & 35.00 & 35.00 & 0.00 & \\
\hline & FFA Compliance & 50.00 & 50.00 & 0.00 & \\
\hline SUM this Sheet & & 2789.25 & 3647.48 & 3138.65 & \\
\hline $\begin{array}{c}\text { Misc. Operational } \\
\text { Expenses }\end{array}$ & & & & 545.98 & \\
\hline Contingency & $(15 \%)$ & 418.39 & 547.12 & 552.69 & \\
\hline Sub-Total by Year & & 3207.64 & 4194.61 & 4237.32 & 120.00 \\
\hline $\begin{array}{c}\text { TOTAL COSTs } \\
\text { RESTART Years } \\
1-3\end{array}$ & $\begin{array}{l}\text { Assume MK } \\
\text { Ferguson \& } \\
\text { Engineering } \\
\text { Involvement }\end{array}$ & & & 11759.57 & \\
\hline
\end{tabular}


BSR Costs for Personnel

\begin{tabular}{|c|c|c|c|c|c|c|c|}
\hline Work Area & $\begin{array}{c}\text { Charge rate (x \$1000) } \\
\text { Burdened. Escalated * } \\
1.04 / \text { vear after Year 1 }\end{array}$ & $\begin{array}{c}\text { FTEs Year 1 } \\
\text { Restart }\end{array}$ & Year 1 S & $\begin{array}{c}\text { FTEs Year 2 } \\
\text { Restart }\end{array}$ & Year 2 S & $\begin{array}{c}\text { FTEs Year 3 - } \\
\text { Operation }\end{array}$ & Year 3 S \\
\hline $\begin{array}{c}\text { Facility } \\
\text { Management }\end{array}$ & 130.00 & 1.50 & 195.00 & 2.00 & 270.40 & 2.00 & 281.22 \\
\hline $\begin{array}{c}\text { Admin } \\
\text { Support }\end{array}$ & 45.00 & 0.50 & 22.50 & 1.00 & 46.80 & 1.00 & 48.67 \\
\hline Compliance & 136.00 & 0.50 & 68.00 & 0.10 & 14.14 & 0.10 & 14.71 \\
\hline $\begin{array}{c}\text { Engineering } \\
\text { Design }\end{array}$ & 117.00 & 0.25 & 29.25 & 0.25 & 30.42 & 1.00 & 126.55 \\
\hline $\begin{array}{c}\text { Engineering } \\
\text { Analysis }\end{array}$ & 170.00 & 1.00 & 170.00 & 1.00 & 176.80 & 1.00 & 183.87 \\
\hline Iraining & 72.00 & 0.25 & 18.00 & 1.00 & 74.88 & 1.00 & 77.88 \\
\hline QA & 103.00 & 0.50 & 51.50 & 0.50 & 53.56 & 0.50 & 55.70 \\
\hline SROs & 110.00 & 1.00 & 110.00 & 5.00 & 572.00 & 5.00 & 594.88 \\
\hline ROs & 96.00 & 2.00 & 192.00 & 10.00 & 998.40 & 10.00 & 1038.34 \\
\hline Maint & 109.00 & 3.00 & 327.00 & 3.00 & 340.08 & 3.00 & 353.68 \\
\hline HPs & 100.00 & 1.00 & 100.00 & 1.00 & 104.00 & 1.00 & 108.16 \\
\hline Security & 100 (fixed cost) & Fixed cost & 100.00 & Fixed cost & 104.00 & Fixed cost & 108.00 \\
\hline TOTALS & & 11.50 & 1383.25 & 24.85 & 2785.48 & 25.60 & 2991.65 \\
\hline
\end{tabular}


Miscellaneous Operating Expenses

\begin{tabular}{|c|c|c|c|}
\hline & & ORR & BSR \\
\hline Utilities & Steam & 23.53 & 4.71 \\
\hline & Water & 35.29 & 7.06 \\
\hline & Air & 11.76 & 2.35 \\
\hline & Electricity & 188.24 & 37.65 \\
\hline Miscellaneous & & 288.00 & 240.00 \\
\hline Sum & 546.82 & 291.76 \\
\hline Overhead & 251.54 & 134.21 \\
\hline Fuel & 330.00 & 120.00 \\
\hline Totals & & 1128.36 & 545.98 \\
\hline
\end{tabular}


Attachment 3

ORNL MOLYBDENUM-99 ESTIMATE

ANNUAL OPERATING COST - TARGET PREPARATION AND

IRRADIATED TARGET PROCESSING

(in FY 1995 dollars)

\section{Cost Element \\ Labor \\ Monthly (9) \\ Weekly (13)}

Fringe Benefits

Division/Section Administration

\section{Materials}

Uranium-235 (net at 70\%)

Major procurement

Other materials and supplies

Support Services

Maintenance and repair

Instrument maintenance

Health Physics

Analytical Chemistry

Quality Assurance

Traffic

Subtotal

Utilities

Waste disposal

Subtotal

Total
Cost in $\$ 000$

Direct $\quad$ G\&A + GPS $\quad$ Total

$$
535
$$

1,071

536

1,607

\section{5}

429

1,715

108

$\underline{215}$

859

323

644

2,574

78
125

$\frac{75}{278}$

278

127

81

170

50

25

42

495

200

50

250

100

$\underline{25}$

125

75

375

2,738

1,280

4,018

135

113

326

190

122

255

75

38

63

743

00

$\begin{array}{lll}2,738 & 1,280 & 4,018\end{array}$




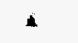


ORNL/TM-13184

\section{INTERNAL DISTRIBUTION}

1. W. S. Aaron

2. C. W. Alexander

3. B. R. Appleton

4. J. M. Begovich

5. J. E. Bigelow

6. R. L. Cline

7-16. E. D. Collins

17. A. G. Croff

18. M. Du

19. G. F. Flanagan

20. H. A. Glovier

21. W. E. Hill

22. G. J. Hirtz

23. R. W. Hobbs

24. H. T. Kerr

25. J. A. Klein

26. F. F. Knapp

27. L. E. McNeese
28. G. E. Michaels

29. S. Mirzadeh

30. C. L. Ottinger

31. B. D. Patton

32. D. E. Reichle

33. J. B. Richard

34. J. A. Setaro

35. R. L. Stover

36. J. H. Swanks

37. J. R. Trabalka

38. J. G. Tracy

39. C. D. West

40. R. M. Wham

41-42. Central Research Library

43. Document Record Section

44. Lab Records, ORNL - RC

45. ORNL Patent Section

\section{EXTERNAL DISTRIBUTION}

46. L. W. Boyd, Department of Energy, Oak Ridge National Laboratory, P. O. Box 2008, Oak Ridge, TN 37831-6390

47. J. A. Brasier, Idaho National Engineering Laboratory, P. O. Box 1625, Idaho Falls, ID 83415

48. J. S. Carty, GTN/NE-70, U.S. Department of Energy, 19901 Germantown Road, Germantown, MD 20874-1290

49. R. L. Coats, Sandia National Laboratory, P. O. Box 5800, KAFB, NM 87115

50. S. F. Laflin, Idaho National Engineering Laboratory, P. O. Box 1625, Idaho Falls, ID 83415

51. O. W. Lowe, GTN/NE-70, U.S. Department of Energy, 19901 Germantown Road, Germantown, MD 20874-1290

52. D. C. Mecham, Idaho National Engineering Laboratory, P. O. Box 1625, Idaho Falls, ID 83415

53. E. Peterson, Los Alamos National Laboratory, MS-J514, Los Alamos, NM 87545

54. R. E. Schenter, Pacific Northwest Laboratory, P. O. Box 1970, MS-HO31, Richland, WA 99352

55-56. Office of Scientific and Technical Information, P. O. Box 62, Oak Ridge, TN 37831 
